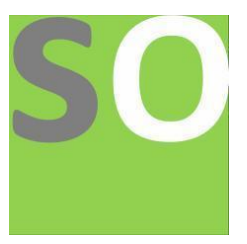

Article title: Speciation and infrageneric classification in the planktonic dinoflagellate Tripos (Gonyaulacales, Dinophyceae)

Authors: Fernando Gomez[1]

Affiliations: Carmen Campos Panisse 3, Puerto de Santa Maria[1]

Orcid ids: 0000-0002-5886-3488[1]

Contact e-mail: fernando.gomez@fitoplancton.com

License information: This work has been published open access under Creative Commons Attribution License http://creativecommons.org/licenses/by/4.0/, which permits unrestricted use, distribution, and reproduction in any medium, provided the original work is properly cited. Conditions, terms of use and publishing policy can be found at https://www.scienceopen.com/.

Preprint statement: This article is a preprint and has not been peer-reviewed, under consideration and submitted to ScienceOpen Preprints for open peer review.

DOI: 10.14293/S2199-1006.1.SOR-.PPWONUQ.v1

Preprint first posted online: 31 August 2020

Keywords: Ceratium, Dinoflagellata, Dinophyta, phytoplankton, plankton, systematics, dinoflagellate, Dinophyceae, Tripos, taxonomy 


\title{
Speciation and infrageneric classification in the planktonic dinoflagellate Tripos (Gonyaulacales, Dinophyceae)
}

\author{
Fernando GÓMEZ \\ Carmen Campos Panisse 3, 11500 Puerto de Santa María, Spain
}

Email: fernando-gomez@ fitoplancton.com 


\section{ScienceOpen Preprints}

Abstract The genus Tripos, formerly marine species of Ceratium, is the dinoflagellate with the greatest number of species and infraspecific taxa $(\sim 800)$ due to the high morphological intraspecific variability of numerous species. In the past, the species of Tripos were proposed into distinct genera. A re-instatement of this generic split is not justified due the difficulties to circumscribe the basal subgenera Amphiceratium and Archaeceratium, and the polyphyletic character of Biceratium. A new infrageneric classification is proposed. The subgenus Amphiceratium is dismembered after the classification of the sections Inflata and partially Fusiformia into Archaeceratium. The subgenus Tripos (autonym) replaces other names such as Tripoceratium or Orthoceratium. Based on the original descriptions, the records of T. furca and $T$. lineatus correspond to T. eugrammus and T. furca, respectively, and T. macroceros has been reported as $T$. contrarius. The names $T$. belone and $T$. carriensis have been misapplied for T. pacificus and T. volans, respectively. Tripos arcuatus, T. gracilis, T. inclinatus, T. scapiformis and T. subcontortus are revived to replace T. euarcuatus, T. declinatus, $T$. horridus, T. longirostrum and T. contortus, respectively. The species T. ramakrishnae and $T$. fusus var. schuettii were described from individuals infected by endoparasites. Tripos rotundatus comb. nov. is proposed for $C$. digitatum var. rotundatum. As a result of taxonomic revision, Tripos is restricted to 57 correct species, although the speciation and synonymy is largely incomplete due to lack of studies in the life cycle and molecular data.

Key words Ceratium; Dinoflagellata; Dinophyta; phytoplankton; plankton; systematics

\section{Abbreviations:}

auct. mult: auctorum multorum $=$ subsequent authors used the name in a different sense to the original author.

bp: base pairs 


\section{ScienceOpen Preprints}

I.C.N.: International Code of Nomenclature for algae, fungi, and plants.

ITS rRNA: Internal Transcriber Spacer of the ribosomal RNA.

LSU rRNA: large subunit of the ribosomal RNA.

nom. illegit.: nomen illegitimum = illegitimate name. A validly published name that is not in accordance with specified rules of the I.C.N.

nom. inval:: nomen invalidum $=$ invalid name. A name not validly published in accordance with specified rules of the I.C.N.

sensu auct.: sensu auctorum $=$ in the sense of certain authors.

SSU rRNA: small subunit of the ribosomal RNA.

\section{Introduction}

The family Ceratiaceae within the Gonyaulacales contains a few freshwater species classified in the genus Ceratium, and numerous marine species classified in Tripos. The species are typically large and robust, often with horns, facilitating the net sampling. In addition, the apparently easy identification using only gross morphology (i.e. outline, including horns) has facilitated abundant information on the distribution, using the species as ecological indicators. Due to the morphological variability, Tripos is the dinoflagellate genus with the greatest number of species and infraspecific taxa ( 800) with an embroiled synonymy and unresolved species circumscriptions. The taxonomy is largely reported in the dinoflagellate literature (Balech, 1988; Schiller, 1937; Steidinger and Tangen, 1997; Taylor, 


\section{ScienceOpen Preprints}

1976), and monographic studies (Graham and Bronikowsky, 1944; Jørgensen 1911, 1920; Peters 1932; Sournia, 1968; Steemann Nielsen, 1934; Subrahmanyan, 1968).

In the late XIX century, the species were classified in several genera (Amphiceratium, Archaeceratium, Biceratium, Ceratium, Euceratium), but since 1908 were unified into Ceratium (Kofoid, 1908b). The marine and freshwater species showed morphological and ecological differences, and they clustered into distinct clades in the molecular phylogeny (Gómez et al., 2010). The genus Tripos was re-instated to encompass the marine species, while the genus name Ceratium remains for the freshwater species that contained the type species (Gómez, 2013). The infrageneric classification of the genus Tripos has remained almost invariable in the last century. In this study, the infrageneric classification is updated based on the molecular data, the synonymy is revised, and a list of correct species names is provided.

\section{$2 \quad$ Materials and methods}

Observations of Tripos were carried out from the North, equatorial and South Pacific Ocean, Caribbean Sea off Puerto Rico, Atlantic South off Brazil, European North Atlantic and the Mediterranean Sea following the methods in Gómez et al. (2010). DNA sequences were retrieved from GenBank. The LSU rRNA gene phylogeny is poor represented because sequences of only nine species are available. The sequence JQ638944 retrieved as T. balechii is labelled as a SSU, LSU and ITS sequence, although it only contains a LSU rRNA gene sequence fragment. The sequence JQ638947 retrieved as T. balechii is unrelated to the genus. Other sequence retrieved as T. balechii (KT389993) is an environmental sequence, and more closely related to $T$. massiliensis than $T$. balechii. There are two short sequences retrieved as T. massiliensis (MF928001, 317 bp; MF928002, 371 bp). There are two short sequences 


\section{ScienceOpen Preprints}

retrieved as T. furca (MF927997-8, 366 and 368 bp, respectively). A longer sequence retrieved as T. furca (AY027908) belongs to an undetermined species of Protogonyaulax.

After Gómez et al. (2010), there are no new documented SSU rRNA gene sequences longer than $1100 \mathrm{bp}$, with the exception of environmental sequences. The phylogenetic tree was built including new sequences that were short $~ 700$ base pairs or less (MF927973MF927990). The sequence with accession number JQ638929 identified as T. balechii has been excluded because it is too short (339 bp), and there is other longer sequence of the same species. The sequence MF927977 (425 bp) identified as T. candelabrum is excluded because there are other longer sequences of the same species. The sequence MF927978 identified as T. dens is discarded because it contains numerous undetermined nucleotides. SSU- and LSU rRNA gene sequence alignments were accomplished by ClustalW (Larkin et al. 2007) and the evolutionary history was inferred by using the Maximum Likelihood method based on the General Time Reversible model with the default settings (uniform rates, complete deletion of gaps/missing data) in MEGA7 software (Kumar et al., 2016). Bootstrap values were obtained after 1000 replications. Sequences of Protoceratium reticulatum were used for rooting the SSU- and LSU rRNA gene phylogenetic trees.

\section{Results and discussion}

\subsection{Molecular phylogeny of Tripos}

The LSU rRNA gene sequences of Tripos eugrammus (retrieved as T. furca) clustered in the most basal position with full support, followed by $T$. fusus, type of the subgenus Amphiceratium (Figure 1). It should be noted that sequences of representatives of Archaeceratium are missing. In the SSU rRNA gene phylogeny, the sequences of $T$. eugrammus are intermediate between the most basal position of the clades of Archaeceratium 


\section{ScienceOpen Preprints}

and Amphiceratium, and a more distal clade containing the rest of the species (Fig. 2). The molecular data suggest that the members of Archaeceratium and Amphiceratium evolved from a hypothetical common ancestor with a morphology closer to T. eugrammus, with short antapical horns directed posteriorly. The species with antapical horns directed anteriorly, the typical anchor-like shape, are considered more recently evolved forms. The morphology of $T$. pacificus (commonly misidentified as $T$. belone) is intermediate between $T$. eugrammus and Amphiceratium, and $T$. belone $(=T$. incisus) between $T$. eugrammus and the species of Archaeceratium. Unfortunately, DNA sequences of T. pacificus and T. belone are missing to test the hypothesis. The basal topology of the sequences of Archaeceratium and Amphiceratium reminds the Dinophysales, other specious group of dinoflagellates. The basal genera of the Dinophysales sensu stricto are Triposolenia and Amphisolenia (Gómez et al. 2011). Triposolenia and the typical species of Archaeceratium are characterized by a flattened and expanded midbody and they live preferentially at sub-photic depths. The species of Amphisolenia and Amphiceratium are characterized by a strong body elongation. This evolutionary parallelism between Tripos and the Dinophysales is striking. 


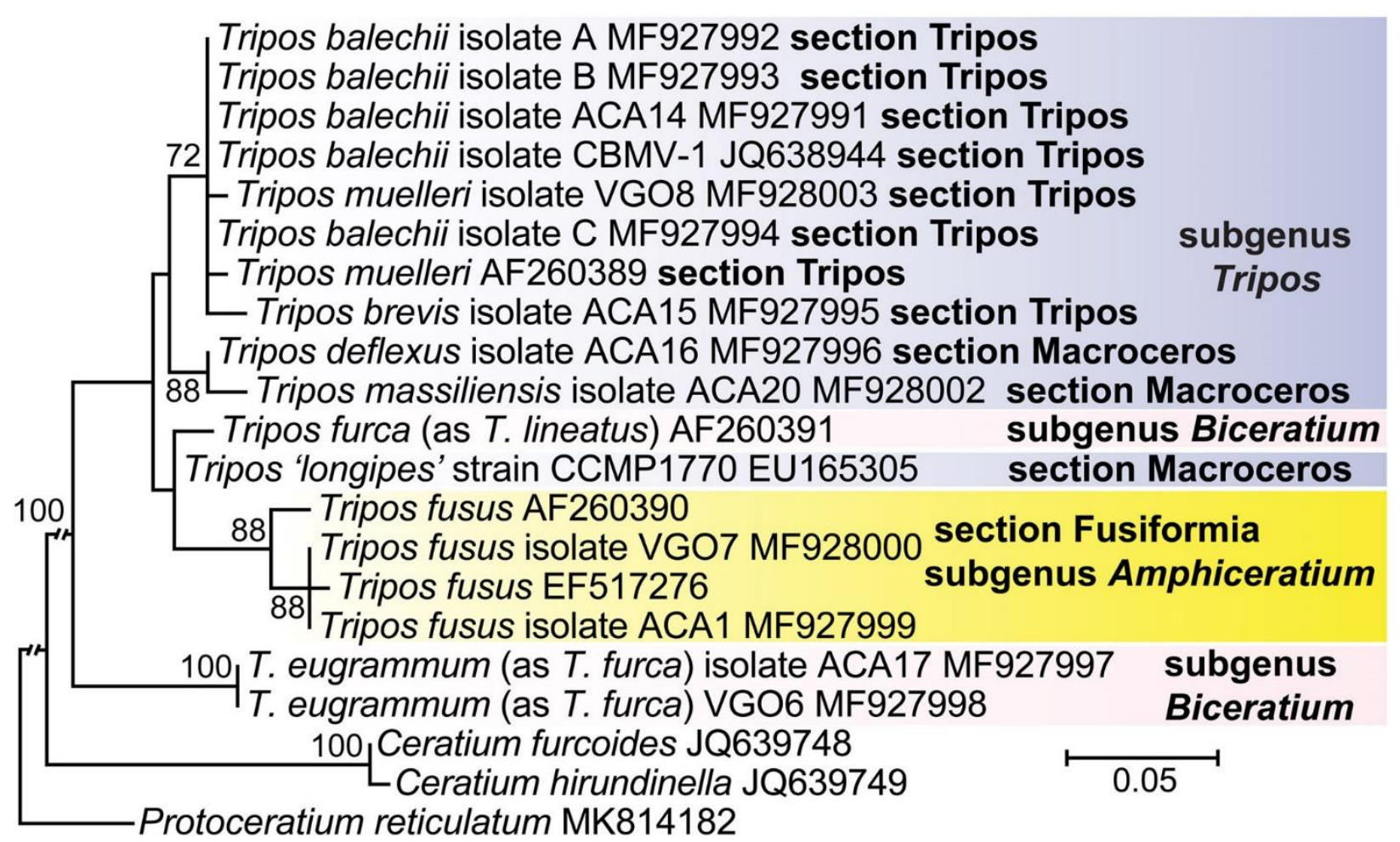

Fig. 1. Phylogenetic tree based on LSU rRNA gene sequences, showing the position of the sequences of Tripos and Ceratium by Maximum Likelihood (ML). The section and subgeneric names are based on the classical taxomonical schemes. A sequence of Protoceratium reticulatum is used as outgroup. Numbers near branches denote ML bootstrap probability value. Bootstrap values $<70$ are omitted. Scale bar denotes 0.05 substitutions per site.

The resolution of the most extended molecular markers for phylogeny of dinoflagellates (SSU- and LSU rRNA gene) is insufficient to solve the relationships in the distal clade. It encompasses most of the species that were classified in the subgeneric names Euceratium, Macroceratium, Orthoceratium or Tripoceratium, and also included some species classified in Biceratium (Fig. 2). The subgeneric name Ceratium must be applied for the freshwater species and the name Euceratium is invalid (article 21.3 of the International Code of Nomenclature, I.C.N.). This distal clade contains the type, T. muelleri, therefore these species 


\section{ScienceOpen Preprints}

belong to the subgenus Tripos that is an autonym (I.C.N., art. 22.1) replacing Orthoceratium sensu Sournia or Tripoceratium.

Authors have admitted four subgenera, and Kofoid (1908c) also added Macroceratium. The distinctive characteristic of Macroceratium is the postindentation, with the bases of the antapicals projected more or less posteriorly beyond the midbody. This trait seems to be supported by the molecular data, and these species cluster together, and in a basal position of the distal clade in some phylogenies. However, the support is insufficient to consider Macroceratium as independent from the subgenus Tripos. 


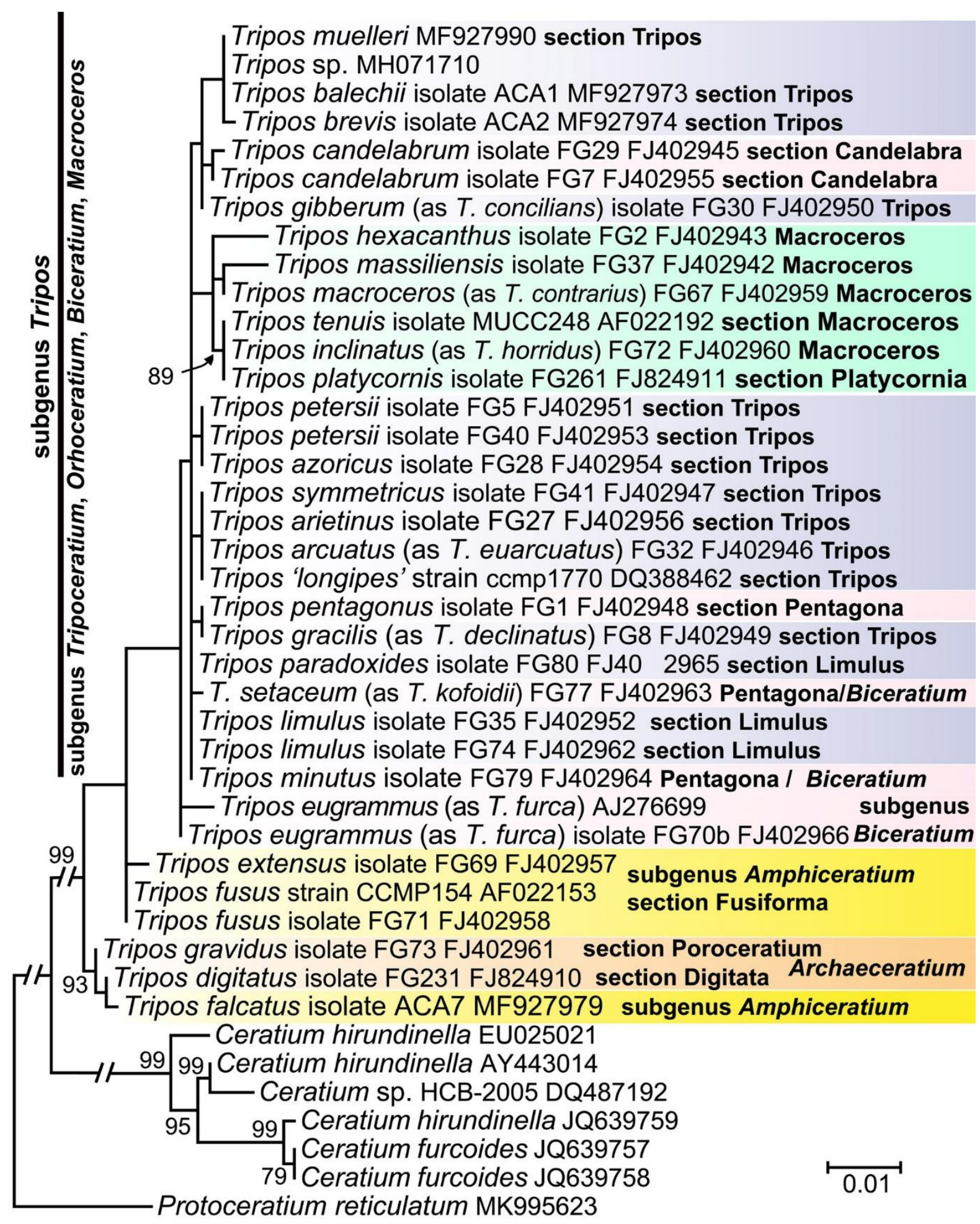

Fig. 2. Phylogenetic tree based on SSU rRNA gene sequences, showing the position of the sequences of Tripos and Ceratium by Maximum Likelihood (ML). The section and subgeneric names are based on the classical taxomonical schemes. A sequence of Protoceratium 
reticulatum is used as outgroup. Numbers near branches denote ML bootstrap probability value. Bootstrap values $<70$ are omitted. Scale bar denotes 0.01 substitutions per site.

\subsection{Subgenus Biceratium}

\subsubsection{Section of Tripos eugrammus (=T. furca auct. mult.).}

Ehrenberg (1834) described Peridinium furca from samples collected at Kiel, Baltic Sea, illustrated in his figure 2 (Fig. 3a, available at https://www.biodiversitylibrary.org/page/29725176 ). Ehrenberg (1860) described $P$. eugrammum from Trieste, Mediterranean Sea, with his figure 4 published in 1873 (Fig. 3b, available at https://digital.zlb.de/viewer/image/15818596/15/ ). Ehrenberg (1854a) described P. lineatum from the Newfoundland, boreal North Atlantic Ocean, and Ehrenberg (1854b) figure it in his figure $25 \mathrm{c}$ in the plate 35 (Fig. 3c, available at https://www.biodiversitylibrary.org/page/50932859 ). The epithecae of $P$. furca and $P$. lineatum are triangular with the apical horn distinct from the rest of the epitheca (Fig. 3a, c), while the epitheca of $P$. eugrammum is gradually tapering into the apical horn (Fig. 3b). The bases of the hypothecae of $P$. furca and $P$. lineatum are almost parallel to the cingulum, while the basis of the hypotheca of $P$. eugrammum is more inclined. The antapical horns of $P$. eugrammum, especially the left one (Fig. 3b), are more robust than those in $P$. furca and $P$. lineatum (Fig. 3a, c). Peridinium lineatum showed shorter antapical horns than P. furca, although this feature may vary intraspecifically as occur in the anterior-most daughter cells. The lateral contour of the hypotheca is almost perpendicular to the cingulum in $P$. lineatum (Fig. 3c), while more inclined in P. furca (Fig. 3a). The comparison of the original illustrations (Fig. 3a-c) evidences that $P$. furca described from subarctic waters and $P$. eugrammum described from a late summer proliferation in the Mediterranean Sea are independent species. More difficult is to solve the identity of $P$. lineatum. 


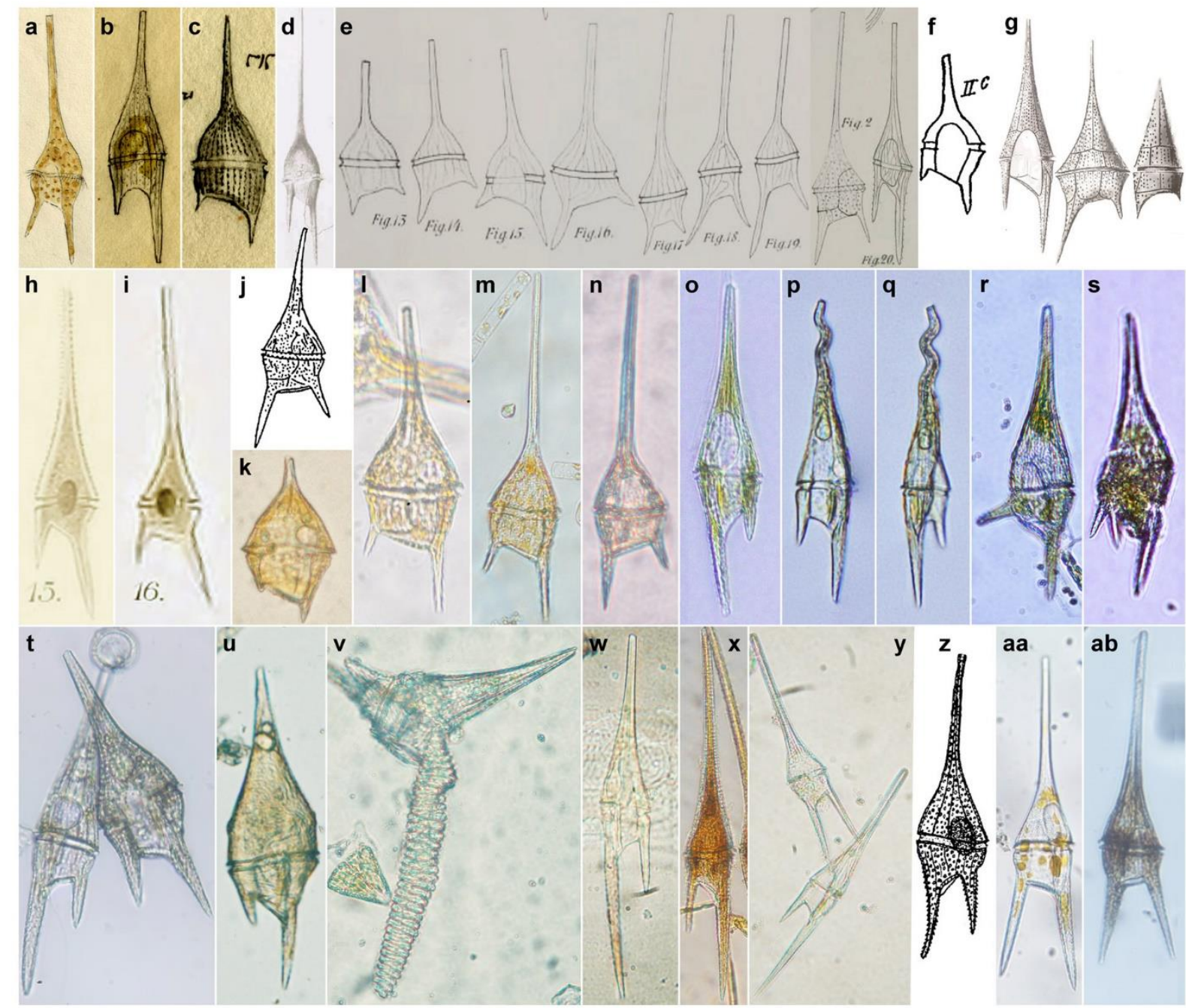

Fig. 3. Line drawings and micrographs of Tripos eugrammus, T. furca, and T. hircus. (a) Peridinium furca by Ehrenberg (1834). (b) P. eugrammum by Ehrenberg (1873). (c) $P$. lineatum by Ehrenberg (1854b). (d) Ceratium furca by Claparède and Lachmann (1859). (e) C. furca by Bergh (1881). (f) C. tripos by Lohmann (1908). (g) C. furca by Stein (1883). (h) Biceratium furca by Vanhöffen (1897). (i) B. debile by Vanhöffen (1897). (j) C. lineatum by Jørgensen (1911). (k) Immature cell. (1-n) T. furca. (o-x). T. eugrammus. (p-s). Aberrant forms. $(\mathrm{t}-\mathrm{v})$ Infected by an endoparasite. $(\mathrm{w}-\mathrm{x})$ Individuals with long antapical horns. $(\mathrm{y}-\mathrm{ab})$ T. hircus. (z) C. hircus by Schröder (1909). 
Ehrenberg's illustrations of $P$. furca and $P$. eugrammum were realistic and enough to facilitate further identifications, but they have been neglected by further authors. The reasons could be problems to access to the Ehrenberg's huge scientific production, with the diagnosis and figure of each new species in distinct publications. Ehrenberg reported the diagnosis of $T$. eugrammus in 1860 and figured it in 1873. Claparède and Lachmann (1859) considered $P$. furca and P. lineatum as synonyms, and they reported an unfortunate illustration of their new combination Ceratium furca. In addition to the excessively thin horns, they figured a chimeric cell with the epitheca of $P$. furca and the hypotheca with the parallel antapical horns that characterizes $P$. eugrammum (Fig. 3d), the latter species undescribed at that time. Further studies did not help to solve this. From the Baltic Sea, Bergh (1881) admitted a high variability of $C$. furca that included individuals with the morphology of $P$. lineatum in his figures 13-14, P. furca in his figures 1-2, 15-19, and P. eugrammum in his figure 20 (Fig. 3e). From the Baltic Sea, Lohmann (1908) reported the morphological variability of C. tripos (Fig. 3f) with forms close to Bergh's illustrations of $C$. furca or Ehrenberg's P. lineatum and P. furca. Lohmann proposed new taxa such as $C$. tripos var. subsalsum f. lineatum that resembled Ehrenberg's $P$. furca. After the supposed high intraspecific variability in Bergh (1881), Stein (1883) considered P. furca, P. eugrammum and $P$. lineatum as a single species named ' $C$. furca Dujard.' (Fig. 3g). Stein was a lumper taxonomist and he illustrated three species as $C$. furca. He figured unrealistic epithecae in most of the illustrations, especially in his figure 11, but the hypothecae were more realistic. Stein's figures 7-10 illustrated individuals with parallel antapical horns that unequivocally correspond to $P$. eugrammus. Stein's figure 11 showed an individual with divergent antapical horns and the shape of the hypotheca of $P$. furca. Stein's figures 13-14 showed individuals with very short antapical horns that fit with 


\section{ScienceOpen Preprints}

Ehrenberg's P. lineatum (Fig. 3g). Vanhöffen (1897) from samples collected near Newfoundland, type locality of $P$. furca, illustrated 'Biceratium furca Dujard.' in his figure 15 (Fig. 3h), and the new species Biceratium debile in his figure 16 (Fig. 3i). Both taxa are synonyms (Fig. 3h-i). The basionym of the type species of the genus and subgenus Biceratium is the boreal species $P$. furca, and Vanhöffen (1897) did not report P. eugrammum. Lemmermann (1899) proposed C. furca var. berghii for the individual of Bergh's figure 20 (Fig. 3e) that corresponds to the morphology of P. eugrammum (Fig. 3e). Jørgensen (1911) considered 'Ceratium furca (Ehrenberg) Dujardin' and C. lineatum as independent species. Jørgensen's illustration of $C$. lineatum showed divergent antapical horns (Fig. 3j) similar to Ehrenberg's $P$. furca (Fig. 3a). Jørgensen (1911) split $C$. furca into two subspecies: berghii for $C$. furca var. berghii, and eugrammum for P. eugrammum. This is unfortunate because $C$. furca var. berghii is P. eugrammum, and none of these two subspecies correspond to the morphology of Ehrenberg's P. furca (Fig. 3a). Jørgensen (1920) reported for C. furca: “This cosmopolitan species was noted from the Mediterranean Sea already by Ehrenberg who described it, 1859, from Trieste as a new species, Peridinium eugrammum”. Jørgensen's synonymy has prevailed up to date and T. eugrammus remains as a junior synonym of $T$. furca. Based on Ehrenberg's illustrations, T. furca (Fig. 3k-n) and T. eugrammus (Fig. 3o-y) are independent species. The records in the literature and the DNA sequences (AJ276699, FJ402966, MF927997-8) reported as T. furca corresponded to T. eugrammus. The records in the literature reported as T. lineatus corresponded to $T$. furca. The DNA sequence (AF260391) retrieved as T. lineatus is not documented, but very likely it corresponds to T. furca. Tripos eugrammus has a wide distribution including tropical seas, while $T$. furca has a preferentially boreal-temperate distribution. Tripos eugrammus reaches high abundances in neritic waters, being common to observe aberrant individuals (Fig. 3p-s) or infected by endoparasites (Fig. 


\section{ScienceOpen Preprints}

$3 \mathrm{t}-\mathrm{v})$. Some individuals of T. eugrammus may show longer antapical horns (Fig. $3 \mathrm{w}-\mathrm{x})$. In warm oceans, T. eugrammus often co-occurred with individuals with antapical horns of almost similar length and slightly divergent as in T. furca. These individuals identified T. hircus (Fig. $3 y-a b)$ are classified in the section Furciformia.

\subsubsection{Section Furciformia (including Pentagona)}

Tripos furca is the type species of the subgenus Biceratium and the section Furciformia. There is only one available LSU rRNA gene sequence (AF260391) retrieved as T. lineatum and it does not cluster with the basal sequences of P. eugrammus (Fig. 1). With the current available data, T. eugrammus is classified in its own section, and T. furca in the section Furciformia. We cannot study the relationship among the members of the sections Furciformia and Pentagona based on the LSU rRNA gene sequences because a single sequence is available (Fig. 1). Based on the SSU rRNA gene phylogeny, the members of Furciformia and Pentagona cluster in distinct clades (Fig. 2). Within this context, the sections Furciformia and Pentagona are merged until further molecular data will clarify this matter. 


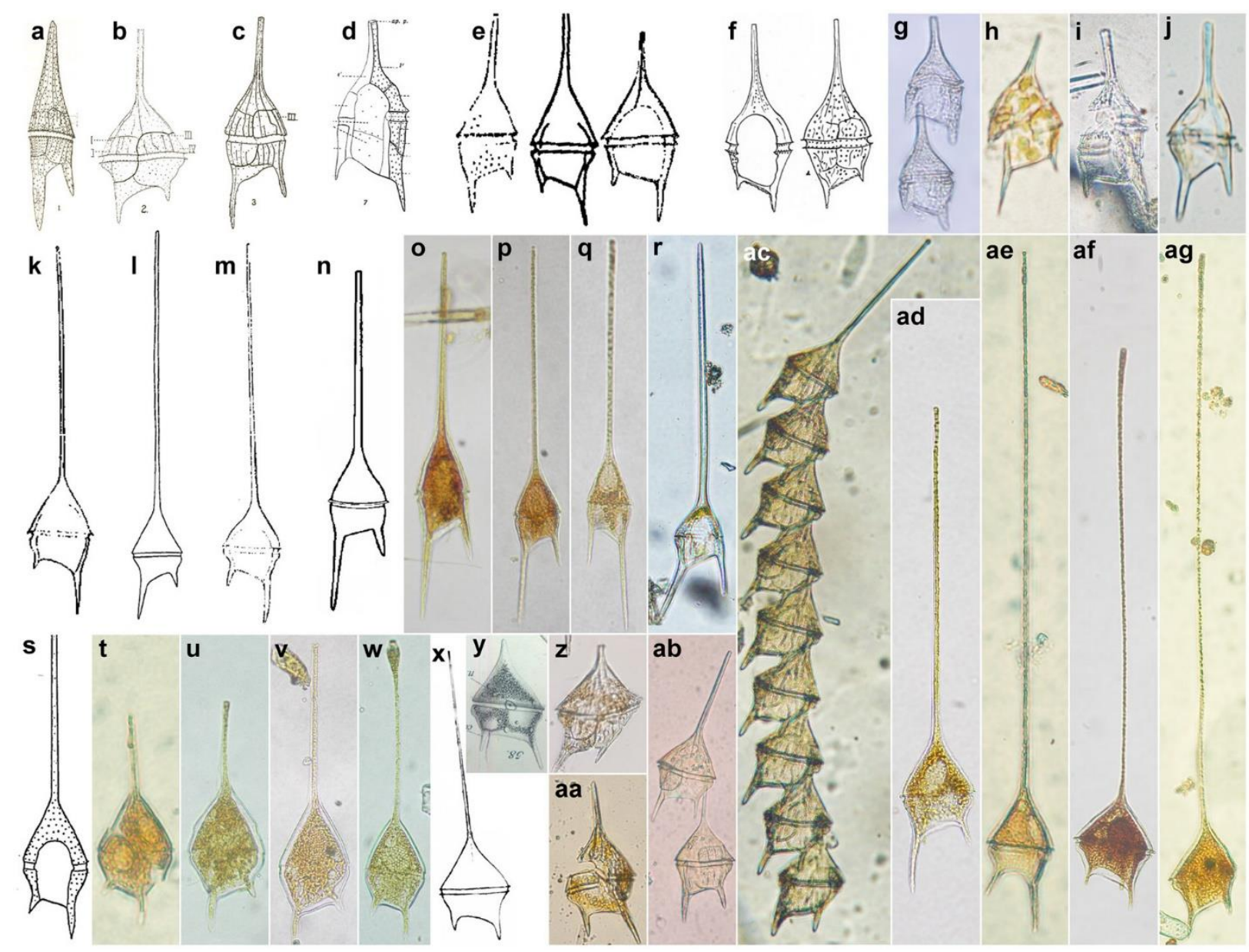

Fig. 4. Line drawings and micrographs of species of the section Furciformia (including Pentagona), and an autotomized cell of the section Macroceros. (a) Ceratium furca by Kofoid (1908a). (b) C. lineatum by Kofoid (1908a). (c) C. eugrammum by Kofoid (1908a). (d) C. eugrammum by Kofoid (1908c). (e) C. minutum by Jørgensen (1920). (d) C. minutum redrawn from Lebour (1925). (g-i). Tripos minutus. (j) Tentative microgamete. (k) C. kofoidii by Jørgensen (1920). (1) C. setaceum by Jørgensen (1911). (m) C. setaceum by Jørgensen (1920). (n) C. boehmii redrawn from Graham and Bronikovsky (1944). (o-q). T. setaceus. (r) Autotomized cell of the section Macroceros, tentatively T. trichoceros. (s-w). T. teres. (s) C. teres by Kofoid (1907b). (x) C. lineatum var. longisetum by Ostenfeld and Schmidt (1901). (y-ag) T. pentagonus. (y) C. pentagonum by Gourret (1883). 


\section{ScienceOpen Preprints}

From individuals collected in the coast of southern California, Kofoid (1908a) tried to clarify the identity of Peridinium eugrammum with questionable results. Kofoid (1908a, his figure 1) as $C$. furca (Fig. 4a) illustrated a cell that corresponded to Ehrenberg's $P$. eugrammum (Fig. 3b). Kofoid (1908a, his figure 2) as C. lineatum (Fig. 4b) illustrated a cell of C. pentagonum (Fig. 4y). Kofoid (1908a, his figure 3) as C. eugrammum (Fig. 4c) illustrated a cell closer to Ehrenberg's $P$. lineatum with longer antapical horns. In other publication, Kofoid (1908c, p. 351, his figure 7) reported as C. eugrammum (Fig. 4d) as cell with short antapical horns that fit with Ehrenberg's P. lineatum (Fig. 3c). Jørgensen (1911) proposed the new species $C$. kofoidii for the figure 3 reported as $C$. eugrammum by Kofoid (1908a) (Fig. 4c). The illustrations of C. kofoidii in Jørgensen (1911) (Fig. 4k), C. setaceum in Jørgensen (1911) (Fig. 4l) and Jørgensen (1920) (Fig. 4m) very likely correspond to a single species (Fig. 4o-q). Graham and Bronikovsky (1944) described C. boehmii (Fig. 4n) that is similar to Jørgensen's illustrations of $C$. kofoidii and C. setaceum, and the slightly longer antapical horns resembled Ehrenberg's $P$. furca (Fig. 3a). We have to be careful to mistake the species of the subgenus Biceratium and individuals of $T$. trichoceros or other members of the section Macroceros which have undergone autotomy of the antapical horns (Fig. 4r). In Jørgensen (1911), the basionym of $C$. kofoidii is $C$. eugrammum in the figure 3 by Kofoid (1908a) (Fig. 4c), but later Jørgensen (1920) proposed the new species $C$. minutum (Fig. 4e) citing again as basionym the figure 3 by Kofoid (1908a) (Fig. 4c). Jørgensen's C. kofoidii is a distinct species from Ehrenberg's $P$. eugrammum and Kofoid's $P$. eugrammum. Ceratium kofoidii (Fig. 4k-1) is here considered conspecific with $C$. setaceum. Then, we can use T. setaceus (Fig. 4o-q) for C. kofoidii and C. boehmii.

Jørgensen (1920) described C. minutum with three illustrations of individuals collected in the European Atlantic, including two individuals collected off west Brittany (Fig. 4e). From 


\section{ScienceOpen Preprints}

samples collected in the English Channel, Lebour (1925) illustrated as C. minutum with individuals showing very short antapical horns (Fig. 4f). The comparison of the original illustration of C. minutum (Fig. 4e) and Ehrenberg's P. lineatum (Fig. 3c) suggest that these taxa may be conspecific. A doubt is whether $P$. lineatum is a morphotype in the life cycle of other species. Short antapical horns are commonly observed in the anterior-most daughter cells of other species. However, T. minutus is not an immature cell because it divides with that morphology (Fig. 4g-i). The sexual life cycle of the species of Tripos is characterized by male microgametes with short horns. It cannot be discarded that developing gametes of T. muelleri or other species could be mistaken as $T$. minutus (Fig. $4 \mathrm{j})$. Ehrenberg's $P$. lineatum and $T$. minutus are considered provisionally as independent species until further research will solve the relationship.

Gourret (1883) described C. pentagonum with a short apical horn (Fig. 4y). In neritic waters, it usually exhibited a short apical horn (Fig. 4z-ab) and sometimes formed colonies (Fig. 4ac). In the open ocean, a long apical horn is more commonly observed (Fig. 4ad-ag), being identified in the literature as $C$. lineatum var. longisetum (Fig. 4x). Kofoid (1907b) described C. teres (Fig. 4s) with short antapical horns and an intermediate shape of the epitheca between T. pentagonus (Fig. 4y) and T. setaceus (Fig. 4m). Tripos teres (Fig. 4t-w) showed a pentagonal cell body more antero-posteriorly elongated than $T$. pentagonus (Fig. 4ad-ag).

\subsubsection{Section Candelabra}

The general appearance of Tripos eugrammus (Fig. 30) resembles the freshwater relatives such as Ceratium hirundinella (Fig. 5a-b), and more especially $C$. furcoides. The latter taxon 


\section{ScienceOpen Preprints}

was also described from a lake as $C$. furca var. lacustre. That similarity is more evident between T. candelabrum (not 'candelabrus') (Fig. 5c) and C. hirundinella (Fig. 5a-b). Tripos candelabrum is a chain-forming species (Fig. 5d-e), while this feature is rare in T. eugrammus and the freshwater Ceratium. Tripos eugrammus is a eurihaline species that often reaches high abundance in low salinity coastal waters. The species of the freshwater genus Ceratium are characterized by the formation of cysts. Resting cysts have been only reported for $T$. eugrammus and T. candelabrum (Gómez et al., 2010). The SSU rRNA gene sequences of $T$. candelabrum cluster with an unresolved relationship with other taxa (Fig. 2), and LSU rRNA gene sequences are not available. Tripos candelabrum and its section Candelabra remains in the subgenus Biceratium based on the superficial resemblance to T. furca. Other molecular markers of $T$. candelabrum are also a priority to clarify the evolution of the genus.

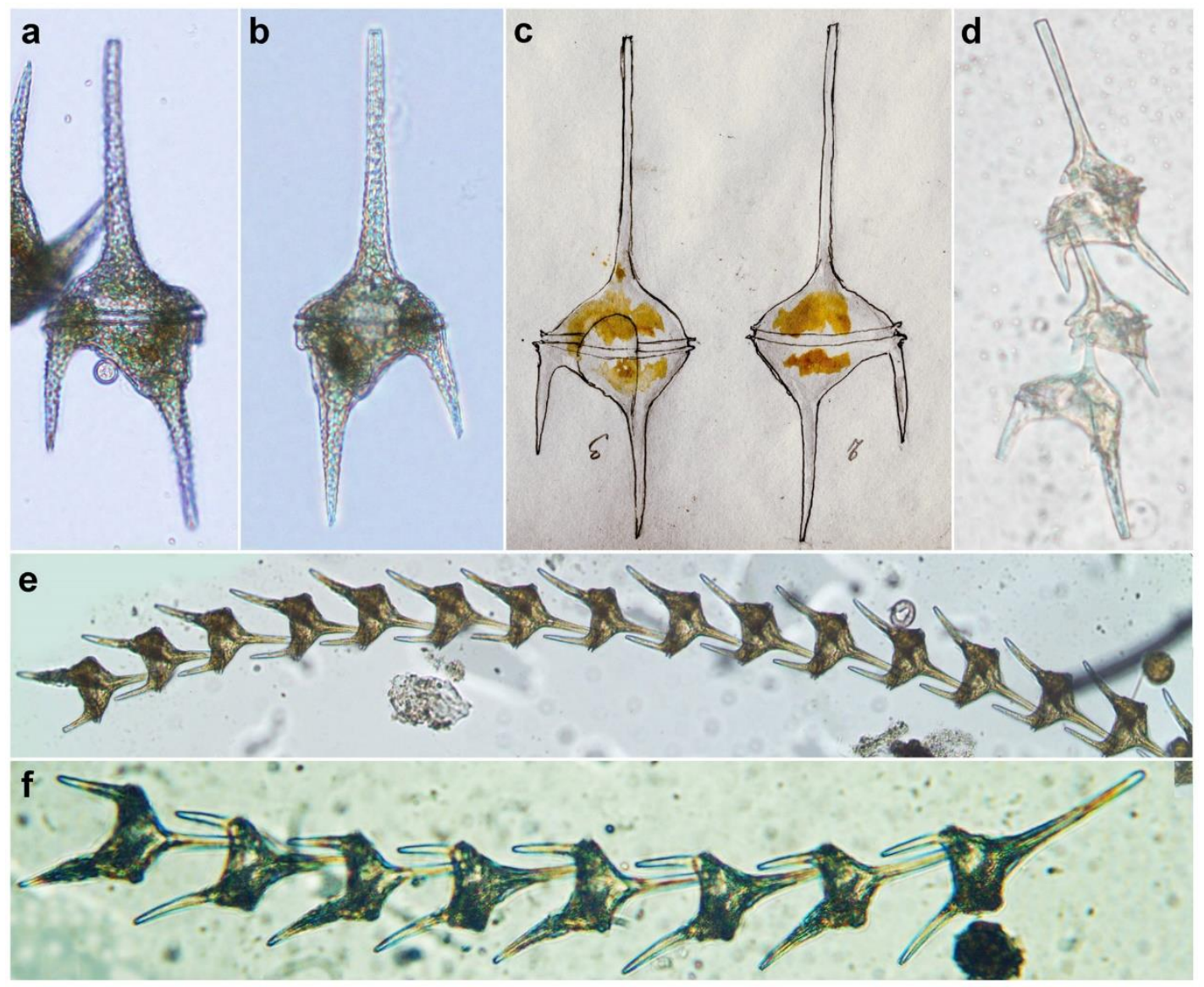




\section{ScienceOpen Preprints}

Fig. 5. Line drawings and micrographs of Ceratium hirundinella, and the section Candelabra of Tripos. (a-b) C. hirundinella. (c) Peridinium candelabrum by Ehrenberg (1873). (d-f) $T$. candelabrum.

\subsection{Subgenus Archaeceratium}

\subsubsection{Section Poroceratium}

The members of Archaeceratium inhabit preferentially in warm oceanic waters and at subphotic depths $(>50 \mathrm{~m})$. The records are rare because most of the samplings are carried out in the surface of temperate coasts. The cell division occurred during the night, and samplings are usually carried out during the day light. Observations of cells under division allow tracking the development of the daughter cells. The anterior- and the posterior-most daughter cells have temporally incomplete antapical and apical horns, respectively. When the cell development is unknown, it is more probable that recently divided cells with incomplete theca could be described as independent species.

The type species of Archaeceratium is Tripos gravidus (Fig. 6a). The records of the close relatives T. cephalotus (Fig. 6b) and T. praelongus (Fig. 6d-g) are less frequent. Are $T$. cephalotus and T. praelongus morphotypes of $T$. gravidus? When a cell divides, the anteriormost daughter cell receives most of the epitheca of the parent cell, and it regenerates the antapical horns and a part of the hypotheca, and vice versa for the posterior-most daughter cell (Fig. 4h-i, aa-ab). Then, at least the epitheca or the hypotheca of the daughter cell should be similar to the parent cell. It is highly probable that we are dealing with an independent species when both epitheca and hypotheca are distinct from the tentative parent cell. The epitheca of T. cephalotus is round (Fig. 6b), while more or less ellipsoidal in T. gravidus or T. 


\section{ScienceOpen Preprints}

praelongus. The hypotheca of $T$. cephalotus has short antapical horns, while $T$. gravidus or $T$. praelongus has longer antapical horns. This suggests that $T$. cephalotus is an independent species. The distinction between $T$. gravidus and T. praelongus is more difficult because they are varieties such as $T$. gravidus var. obovatus with intermediate characteristics (Fig. 6c). I have observed daughter cells that split during the sample treatment. One cell showed a large epitheca of $T$. gravidus and other cell showed a small epitheca with the shape of $T$. praelongus (Fig. 6d). However, other cells kept the morphology of T. praelongus even when they divide (Fig. 6e). The epitheca is incomplete in the posterior-most daughter cells (Fig. 6f-g). Tripos praelongus is considered a morphotype of $T$. gravidus, and the observations should be reported as T. gravidus var. praelongus. 


\section{ScienceOpen Preprints}

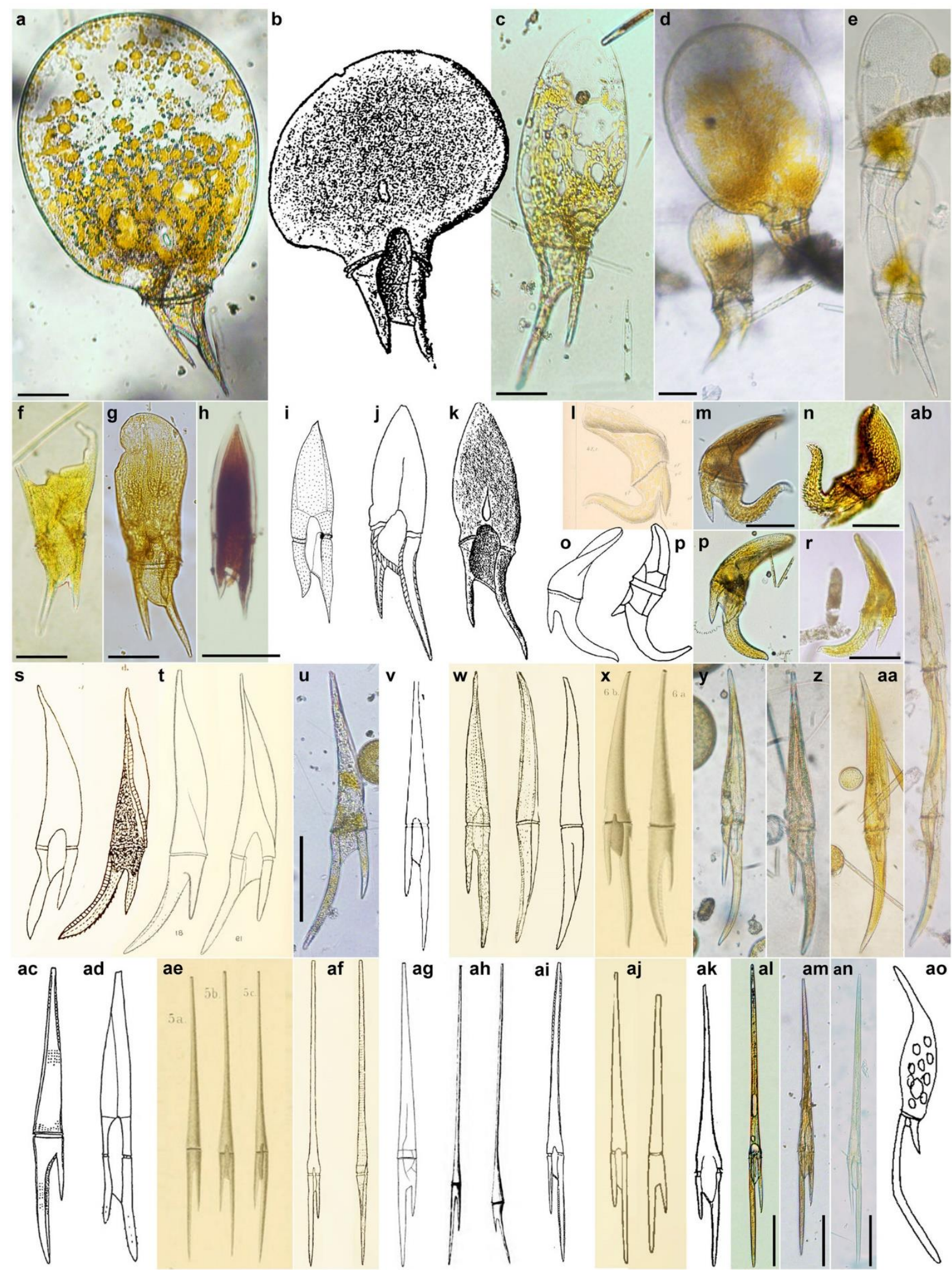




\section{ScienceOpen Preprints}

Fig. 6. Line drawings and micrographs of of species of the subgenus Archaeceratium. (a) Tripos gravidus. (b) Ceratium sp. (=T. cephalotus) in Schütt (1892). (c) T. gravidus var. obovatus. (d-e). Daughter cells of T. gravidus. (d-g) T. gravidus var. praelongus. (h-i) T. lanceolatus. (i) C. lanceolaum by Kofoid (1907a). (j) C. lanceolaum by Gaarder (1954). (k) Ceratium sp. by Schütt (1892). (k-n) T. digitatus. (1) C. digitatum by Schütt (1895). (o-r) T. rotundatus comb. nov. (o) C. digitatum var. rotundatum by Jørgensen (1920). (p) C. tasmaniae redrawn from Wood (1963). (s-u) T. schroeteri. by Schröder (1906). (t) C. shroeteri by Kofoid (1907a). (v-ac) T. belone. (v) C. belone by Cleve (1900). (y) C. belone by Schröder (1906). (x) C. furca var. incisum by Karsten (1906). (ac) C. incisum by Jørgensen (1920). (ad) C. brunellii redrawn from Rampi (1942). (ae-an). T. pacificus. (ae) C. furca var. longum by Karsten (1906). (af) C. pacificum by Schröder (1906). (ag) C. pacificum by Kofoid (1907a). (ah) C. pacificum by Stüwe (1909). (ai) C. belone by Jørgensen (1920). (aj) Smaller cells of C. belone redrawn from Graham and Bronikovsky (1944). (ak) C. furca var. belonoides by Jørgensen (1920). (ao) C. pacificum E.J.F. Wood redrawn from Wood (1963). Scale bars: 50 $\mu \mathrm{m}$.

\subsubsection{Section Lanceolata}

The members of the section Poroceratium are characterized by a pore in the epitheca (Fig. 6ab). The pore has not been reported in the rare species Tripos lanceolatus. Its morphology is intermediate between $T$. praelongus with a pointed epitheca and a straight cell of $T$. schroeteri with shorter antapical horns. My observations from the tropical Eastern Pacific (Fig. 6h) fit well in shape and size with the original description of $C$. lanceolatum by Kofoid (1907a) that described it from the same region (Fig. 6i). Gaarder (1954) identified as C. lanceolatum a 


\section{ScienceOpen Preprints}

large cell (285 $\mu \mathrm{m}$ long) with long and bent antapical horns (Fig. 6j), already illustrated by Schütt (1892) with a pore in the epitheca (Fig. 6k). These observations resembled individuals of T. gravidus var. praelongus with an atypical lanceolate epitheca. Tripos lanceolatus remains in its own section because it is difficult to decide placing it in the sections Poroceratium or Digitata. Other tentative member of Lanceolata could be T. brunellii, only known from the original description by Rampi (1942) (Fig. 6ad).

\subsubsection{Section Digitata}

Tripos digitatus, classified in the earlier taxonomical schemes in the subgenus Biceratium, is classified in Archaeceratium based on the molecular data (Fig. 2, Gómez et al., 2010). It has one antapical horn laterally directed (Fig. 61-n) that does not strictly fit with Kofoid's diagnosis of the subgenus: "Antapical horns subequal, directed posteriorly". Both, the epitheca and hypotheca of $T$. digitatus var. rotundatus (Fig. 6o) are distinct from those in $T$. digitatus (Fig. 61-n). The epitheca of T. digitatus is strongly reflected towards the dorsal side, the left antapical horn is anteriorly directed and the apex showed a short projection (Fig. 61n), while $T$. digitatus var. rotundatus showed an epitheca less bent towards the dorsal side, the short projection in the apex is missing, and the left antapical horn is directed laterally (Fig. 6o-r). Tripos tasmaniae (Fig. 6p) is a synonym of T. digitatus var. rotundatus that Wood (1963) described without citing the similarity. Tripos tasmaniae is the earliest available name at the species rank (I.C.N. art. 11.2), but it is not a validly published name (I.C.N. art. 39.1). The classification of $T$. digitatus var. rotundatus at the species rank is proposed in this study.

In the earlier taxonomical schemes, Tripos schroeteri (non T. schroederi) was classified in the subgenus Biceratium based on the superficial resemblance with T. eugrammus. Tripos schroeteri is classified in Archaeceratium because the epitheca is wide and flat, and the 


\section{ScienceOpen Preprints}

antapical horns are unequal, robust and bent (Fig. 6s-u). Cleve (1900) described Ceratium belone (Fig. 6v), further illustrated by Schröder (1906) (Fig. 6w), and Karsten (1906) that described it as C. furca var. incisum (Fig. 6x). Cleve's illustrations are sketchy and the description of $C$. belone was scarcely detailed. The cell shape of Schröder's and Karsten's illustrations were similar to Cleve's taxon, but their illustrations showed more clearly that the left antapical horn is slightly bent. Tripos incisus is a junior synonym of T. belone. However, Jørgensen (1920) considered C. incisum and C. belone as independent taxa. Jørgensen's figures of C. incisum (Fig. 6ac) and C. belone (Fig. 6ai) corresponded to Cleve's C. belone (Fig. 6v-x) and Schröder's C. pacificum (Fig. 6af), respectively.

\subsubsection{Section of Tripos pacificus (subsection Beloniformia in part)}

Karsten (1906) described C. furca var. longum (Fig. 6ae) and Schröder (1906) described the same taxon as C. pacificum (Fig. 6af). Kofoid (1907a) reported a wider cell as C. pacificum, but it is closer to C. belone sensu Cleve (Fig. 6ag). Stüwe (1909) illustrated individuals that fit with the original description of C. pacificum (Fig. 6ah). Jørgensen (1920) under the name C. belone (Fig. 6ai) figured an elongated cell that corresponded to Schröder's C. pacificum (Fig. 6af). Jørgensen's interpretation of C. belone was questioned by Pavillard (1931, p. 71), but it has prevailed up to date. Graham and Bronikovsky (1944) admitted a high morphological variability of the epitheca of $C$. belone, ranging from individuals that fit with T. pacificus to smaller individuals with a thinner epitheca than in the original description of T. belone (Fig. 6aj). There are warm water taxa such as C. furca var. belonoides that can be mistaken for C. belone (Fig. 6ak). Wood (1963) added confusion when he proposed the later isonym C. pacificum (Fig. 6ao) for individuals of T. geniculatus (Fig. 7a-c). The evolutionary 


\section{ScienceOpen Preprints}

origin of $T$. pacificum can be interpreted in two ways: 1) an elongated cell evolved from a common ancestor with T. eugrammus or T. belone, or 2) a cell with a developed right antapical horn evolved from a common ancestor with T. fusus. Tripos pacificus has a flattened epitheca gradually tapering towards the apex that suggests an affinity with Archaeceratium. Tripos pacificus is here considered a link between Archaeceratium and Amphiceratium. A new section should be proposed for T. pacificus if it is confirmed by the molecular data.

\subsubsection{Section Inflata}

The support to re-classify the members of the section Inflata and most of the members of section Fusiformia into Archaeceratium is based on the molecular data of $T$. falcatus, a species currently classified in the section Fusiformia of Amphiceratium. The SSU rRNA gene sequence retrieved as T. falcatus (MF927979) showed a percentage of similarity of 99.86 and $99.71 \%$ when compared to the sequences of $T$. digitatus and $T$. gravidus, respectively, while the similarity was lower than $99 \%$ when compared to T. fusus. The sequence of T. falcatus clustered with high support with $T$. digitatus and $T$. gravidus (Fig. 2). This suggests that $T$. falcatus and its relatives should be classified in the subgenus Archaeceratium.

Kofoid (1909, p. 219) defined the subgenus Archaeceratium (as Poroceratium) as: "Antapical horns subequal, directed posteriorly. Midbody extends to apical pore. Apical horn not differentiated". The species of the section Inflata of Amphiceratium (i.e., T. geniculatus, Fig. 7a-c), showed a flattened midbody and antapical horns closer to Archaeceratium. Tripos bigelowii (Fig. 7d) is a rare species with an expanded midbody (Fig. 7d). In the current taxonomical schemes, T. geniculatus and T. bigelowii are classified in the section Inflata, while T. inflatus in the section Furciformia (Jørgensen 1911, Sournia 1968). Individuals of $T$. 


\section{ScienceOpen Preprints}

inflatus (Fig. 7e-f) infected by the endoparasite Amoebophrya could be mistaken for $T$. bigelowii (Fig. 7d).

Gourret (1883) described Ceratium longirostrum (Fig. 7g) as a cell with straight horns and the right antapical horn was not visible as typical in T. fusus or T. extensus. Kofoid (1907a, his figure 12) described $C$. pennatum f. propium with slightly bent horns and the right antapical horn very reduced, but visible (Fig. 7h). Despite the significant differences, Jørgensen (1920) reported that C. longirostrum (Fig. 7g) and C. pennatum f. propium (Fig. 7h) are synonyms. Jørgensen's illustration (Fig. 7i) identified as C. longirostrum corresponded to Kofoid's C. pennatum f. propium (Fig. 7h), and not to Gourret's C. longirostrum (Fig. 7g). Gourret (1883) did not report any curvature of the horns in the diagnosis and he reported that his figure 65 showed the dorsal view. Jørgensen (1920) considered that Gourret's illustration showed the side view, but this option is highly improbable. Jørgensen (1920, p. 37) reported the figure 13 of $C$. pennatum f. propium in Kofoid (1907a) as synonym of $C$. longirostrum, but Kofoid's figure 13 corresponded to $C$. pennatum f. inflatum. Further authors have followed Jørgensen's interpretation using the name $C$. longirostrum for $C$. pennatum, and the latter name has disappeared from the literature. The name $T$. pennatus is here revived for $C$. longirostrum auct. mult. (Fig. 7i). Jørgensen (1920) proposed C. falcatum for C. pennatum $\mathrm{f}$. faltacum (Fig. 7k-o). Jørgensen (1920, p. 35) reported that C. fusus var. concavum Gourret (Fig. 7q) is a synonym of $C$. inflatum, but it is closer to $C$. falcatum with a bent apical horn (Fig. 7p). Jørgensen (1911, p. 25) cited “C. concavum auct. p. p.)”, but I am unable to find the proposal of $C$. fusus var. concavum at the species rank. Jørgensen (1920) proposed the new species $C$. falcatiforme (Fig. 7r) for a cell with a wider epitheca than $C$. falcatum (Fig. 7s-t). Kofoid (1907a) described C. scapiforme characterized by a wide epitheca (Fig. 7u). Jørgensen (1911) proposed C. pennatum var. scapiforme, and later reported " $C$. pennatum v. scapiforme 


\section{ScienceOpen Preprints}

Jørgensen 1911, non C. scapiforme Kofoid" as synonyms of $C$. longirostrum (Jørgensen 1920). As occurred with C. pennatum, C. scapiforme (Fig. 7v) has disappeared from the literature after Jørgensen.

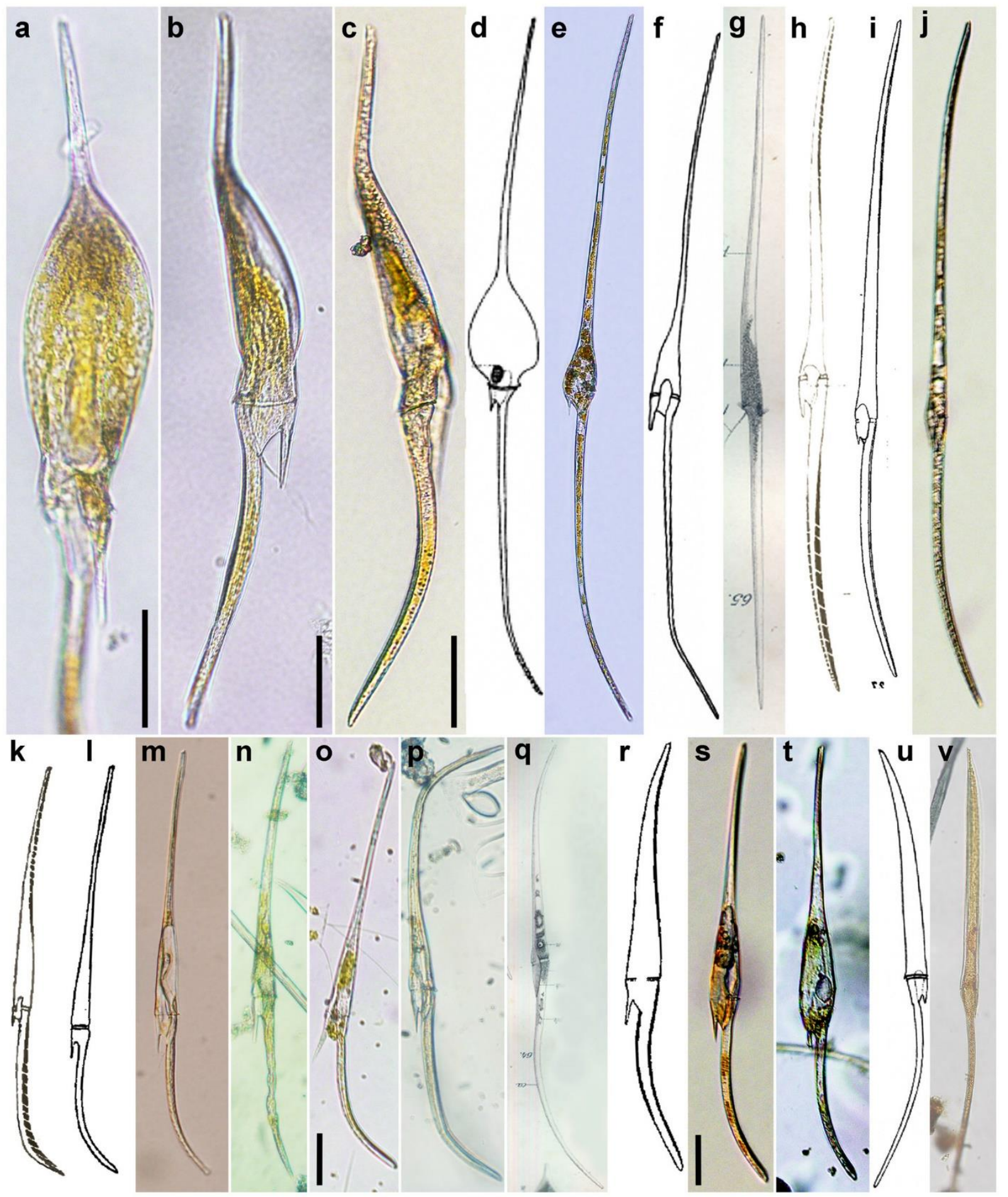




\section{ScienceOpen Preprints}

Fig. 7. Line drawings and micrographs of species of Archaeceratium: section Inflata and some species formerly classified in Fusiforma of the. (a-c) Tripos geniculatus. (d) Ceratium bigelowii by Kofoid (1907a). (e-f) T. inflatus. (g) C. pennatum f. inflatum by Kofoid (1907a, fig. 13). (g) C. longirostrum by Gourret (1883). (h) C. pennatum f. propium by Kofoid (1907a, fig. 12). (i) C. longirostrum by Jørgensen (1920). (j) T. pennatus. (k) C. pennatum f. falcatum by Kofoid (1907a, fig. 14). (1) C. falcatum by Jørgensen (1920). (n-p) T. falcatus. (q). C. fusus var. concavum by Gourret (1883). (r-t) T. falcatiformis. (r) C. faltatum by Jørgensen (1920). (u-v) T. scapiformis. (v). C. scapiforme by Kofoid (1907a, fig. 23). Scale bars: $50 \mu \mathrm{m}$.

\subsection{Subgenus Amphiceratium}

\subsubsection{Section Fusiformia}

Amphiceratium is dismembered after the classification of the section Inflata and most of the species of the section Fusiformia in Archaeceratium. Amphiceratium is here restricted to $T$. fusus and very closely allied taxa with an elongated cell body along the antero-posterior axis with almost straight horns, and a reduced or almost invisible right antapical horn (Fig. 8a). The type species $T$. fusus, is together with T. eugrammus, one of the more common species in temperate coastal waters. In addition to the individuals under division (Fig. 8b), it can be observed teratogenic or aberrant forms (Fig. 8c-e). Schütt's (1895) illustrated an individual of $C$. fusus with a wide epitheca (Fig. 8f) that was later reported as the variety $C$. fusus var. schuettii. It corresponds to individuals of T. fusus infected by the endoparasite Amoebophrya (Fig. 8g). Claparède and Lachmann (1859) reported illustrations identified as C. furca (Fig. 3d) and C. biceps (Fig. 8h) with atypical morphologies that have not been further reported. 


\section{ScienceOpen Preprints}

Most of the authors have considered that they correspond to a single species, placing C. biceps as a synonym of T. eugrammus (=C. furca auct. mult.). As illustrated by Stein (1883), $C$. biceps resembles the lateral view of T. eugrammus (Fig. 8i) or its anterior-most daughter cell (Fig. 8j). Gourret (1883) described C. fusus var. extensum as a very elongated cell (Fig. 81). Jørgensen (1911, p. 27) considered C. biceps sensu Kofoid 1908c as C. strictum, and Taylor (1976) considered C. biceps as an immature cell of C. extensum. Kofoid (1908c, his figure 21-23) induced the error when he assumed a high variability for C. biceps (Fig. 8j). During the cell division of T. extensus, the anterior-most daughter cell received the apical horn from the parent cell, and the posterior-most cell received the long left antapical horn (Fig. 8r-v). The daughter cell that receives the short right horn from the parent cell has been identified as C. strictum (Fig. 8t-v). Kofoid (1908c) illustrated a cell with short apical and antapical horns (Fig. 8j). This is atypical and Kofoid very likely misidentified an anterior-most daughter cell of T. eugrammus (Fig. 8k) with a life stage of T. extensus. Tripos extensus (Fig. 8m-n) is a thermophilic species unreported for the North Sea, and Claparède and Lachmann (1859) did not observe it (Fig. 8h) in the cold waters of a Norwegian fjord where T. eugrammus is present (Fig. 8i). Ceratium biceps (Fig. 8h) is an immature cell of T. eugrammus (Fig. 8k). The molecular data confirmed that T. extensus is distinct from T. fusus (Gómez et al., 2010), but there are individuals with intermediate characteristics between both species that need research. The species diagnoses based on the length of the horns are risky because it depends of the degree of maturation after the division or the potential autotomy (Fig. 8r-s). The name $T$. longirostrum is available for a species with intermediate characteristics between T. fusus and T. extensus (Fig. 8o-q). 


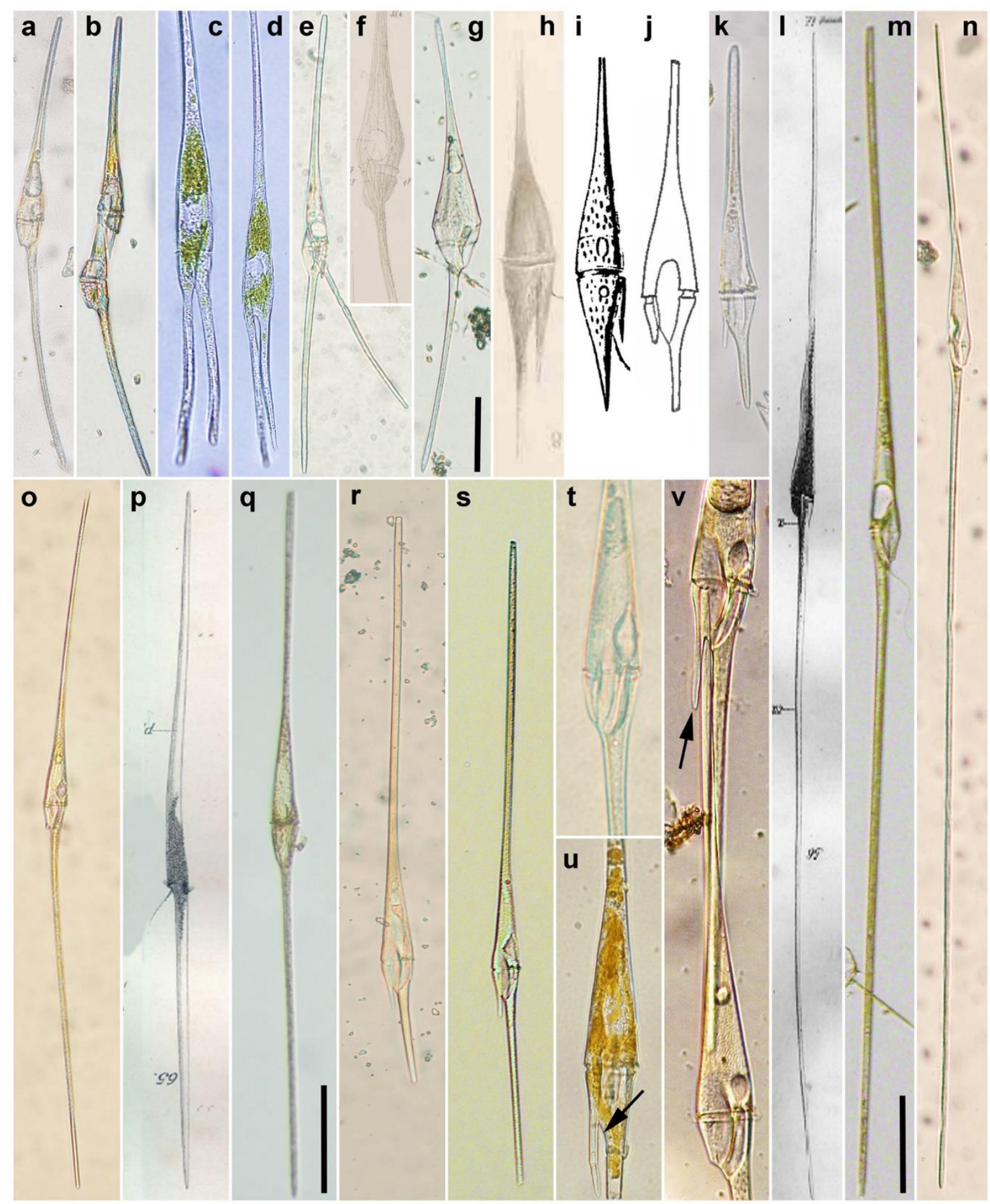

Fig. 8. Line drawings and micrographs of species of the section Fusiformia of the subgenus Amphiceratium. (a-g) Tripos fusus. (b) Cell under division. (c-e) Aberrant forms. (f) Ceratium fusus by Schütt (1895). (g) Cell infected by endoparasite Amoebophrya, known as Ceratium fusus var. schuettii. (h) C. biceps by Claparède and Lachmann (1859). (i) C. furca 


\section{ScienceOpen Preprints}

by Stein (1883). (j) C. biceps by Kofoid (1908c, fig. 23). (k) Immature cell of T. eugrammus. (1-n) Tripos extensus. (k) C. fusus var. extensum by Gourret (1883). (o-q) Tripos longirostrum. (p) C. longirostrum by Gourret (1883). ( $\mathrm{r}-\mathrm{v})$ Immature individuals of $T$. longirostrum or T. extensus. $(\mathrm{u}-\mathrm{v})$. The arrow points the right antapical horn. Scale bars: 50 $\mu \mathrm{m}$.

\subsection{Subgenus Tripos}

Based on the SSU rRNA gene sequence phylogeny, the species of the clade that contains the type, T. muelleri, and distantly related to the sequences of the types of Archaeceratium, Amphiceratium and Biceratium, should be grouped into a single subgenus named Tripos, an autonym (Fig. 2). Most of the authors have split the species of Tripos into four subgenera: Amphiceratium, Archaeceratium (=Poroceratium), Biceratium (=Ceratium, Orthoceratium Meunier) and Tripoceratium (=Euceratium, Orthoceratium Sournia). Kofoid (1909) proposed the subgenus Macroceratium for some species formerly classified in Tripoceratium $(C$. macroceros, C. gallicum, C. vultur) which "bases of the antapicals projected more or less posteriorly beyond midbody forming a postindentation", while Tripoceratium was restricted to species with “postmagin rounded, no postindentation". Kofoid (1909) was fortunate and the postindentation is a trait supported by the molecular phylogeny, although the molecular divergence is not high to support the classification of Macroceratium as independent from the subgenus Tripos (Fig. 2). The antapical horns of the species of Amphiceratium, Archaeceratium and Biceratium are directed posteriorly, while there is more variability in the species of the subgenus Tripos. In the asexual life cycle, anterior-most daughter or 


\section{ScienceOpen Preprints}

autotomized cells show posteriorly directed antapical horns, while they bent and were anteriorly directed in the mature cells. This feature, together with the variability in the length of the horns due to environmental conditions (i.e., seasonality) are factors that induce a high variability of outlines. Consequently, it is even more difficult to establish the synonymy and species circumscriptions in the subgenus Tripos due to the numerous intermediate morphologies.

\subsubsection{Section Macroceros (=Protuberantia)}

Ehrenberg (1840, p. 201) described Peridinium macroceros with a brief diagnosis. Ehrenberg's illustration of P. macroceros (Fig. 9p) from an individual collected at Cuxhaven, German North Sea, is available at the Ehrenberg's collection at: $\underline{\text { http://download.naturkundemuseum- }}$

berlin.de/ehrenberg/Ec\%20Drawings/Ec\%20draw\%20001-999/Ec\%20draw\%20900-

999/ECdraw950.jpg ). Further authors have interpreted $P$. macroceros as the species illustrated by Claparède and Lachmann (1859). This time, Claparède and Lachmann's illustration is realistic (Fig. 9a), but it is not conspecific with Ehrenberg's P. macroceros (Fig. 9p). Ceratium tripos var. macroceros by Claparède and Lachmann showed a prominent postindentation (Fig. 9a), while Ehrenberg's $P$. macroceros showed a scarce postindentation (Fig. 9p). In further literature, the species with the prominent postindentation have been assigned to C. macroceros (Fig. 9a-c, e-f). Only, the illustration of 'Ceratium tripos var. macroceras f. armata' (Fig. 9d) by Karsten (1905, his plate 19, figs 7, 8) fit with Ehrenberg's P. macroceros, but Karsten (1905) was no coherent because his ' $C$. tripos var. macroceras Ehrenberg' (his plate 22, figure 29) showed a prominent postindentation and it is not conspecific with his form 'armata'. To the best of my knowledge, nobody has interpreted correctly Ehrenberg's $P$. macroceros because the diagnosis was not enough detailed, and the 


\section{ScienceOpen Preprints}

illustration could not be accessible. What to do? The basionym of T. macroceros is $P$. macroceros as described by Ehrenberg (1840), and the diagnosis corresponds to the species figured by him (Fig. 9p), and not further interpretations. Then, C. macroceros auct. mult. needs other species name. The earlier name at the rank level for this species could be $C$. gallicum (Fig. 9e). Ceratium deflexum was later ranked at the species level (Fig. 9f). Under the name $T$. gallicus are included individuals with a progressive curvature of the antapical horns as C. macroceros sensu Claparède and Lachmann (Fig. 9g-j), and individuals with a more abrupt deflection angle of the antapical horns (Fig. 9k) that fit better with the original description of $C$. gallicum. Further research is needed to confirm if both forms are conspecific. Tripos massiliensis is a closely related species to $T$. gallicus, but with a less prominent postindentation (Fig. 91-n). Ehrenberg's P. macroceros (Fig. 9p, u-w) shows a scarce postindentation when compared to $C$. gallicum and $C$. massiliense. Junior synonyms of $P$. macroceros also described from the North Sea are C. batavum (Fig. 9r) and C. intermedium (Fig. 9s), and from other regions are C. contrarium (Fig. 9q) and C. protuberans (Fig. 9t).

From the coasts of Marseilles, Gourret (1883) described C. tripos var. inflexum (Fig. 9x), C. tripos var. typicum (Fig. 9y) and C. carriense (Fig. 9z). Gourret's illustration of $C$. carriense is the anterior-most daughter cell of $C$. tripos var. typicum, and $C$. tripos var. inflexum is an aged cell of the same species that was further described as C. flagelliferum (Fig. 9aa). Gourret used 'typicum' to remark that this form was common in the coasts of Marseilles, and this should not be interpreted as the typical morphology of $C$. tripos (now $T$. muelleri). Based on my experience after one year of daily plankton samplings at the coasts of Marseilles, this species is common and abundant there (Fig. 9ab). Individuals of T. carriensis infected by an endoparasite showed an inflated midbody (Fig. 9ac-ad), and they have been described as C. ramakrishnae (Fig. 9ae). Tripos carriensis is characterized by antapical horns that bent at 


\section{ScienceOpen Preprints}

the same height (Fig. 9x-ae). Tripos trichoceros is more slender and an oceanic species which antapical horns bent at different heights (Fig. 9af-ah). Gourret (1883) proposed C. carriense for an immature individual and this may induce confusion. Jørgensen (1920) and further authors misinterpreted the identity of $C$. carriense. Jørgensen illustrated an individual with the antapical horns bent at different heights, with a short curvature of the proximal region of the left antapical horn (Fig. 9ai, al-am). The tentative earlier name for Jørgensen's $C$. carriense is T. volans (Fig. 9aj), and it is also closely related to T. tenuis (Fig. 9ak). Questionable species are C. uncinus (Fig. 9an) or C. californiense (Fig. 9ao-ap) that can be considered aberrant forms of species of the section Macroceros. 


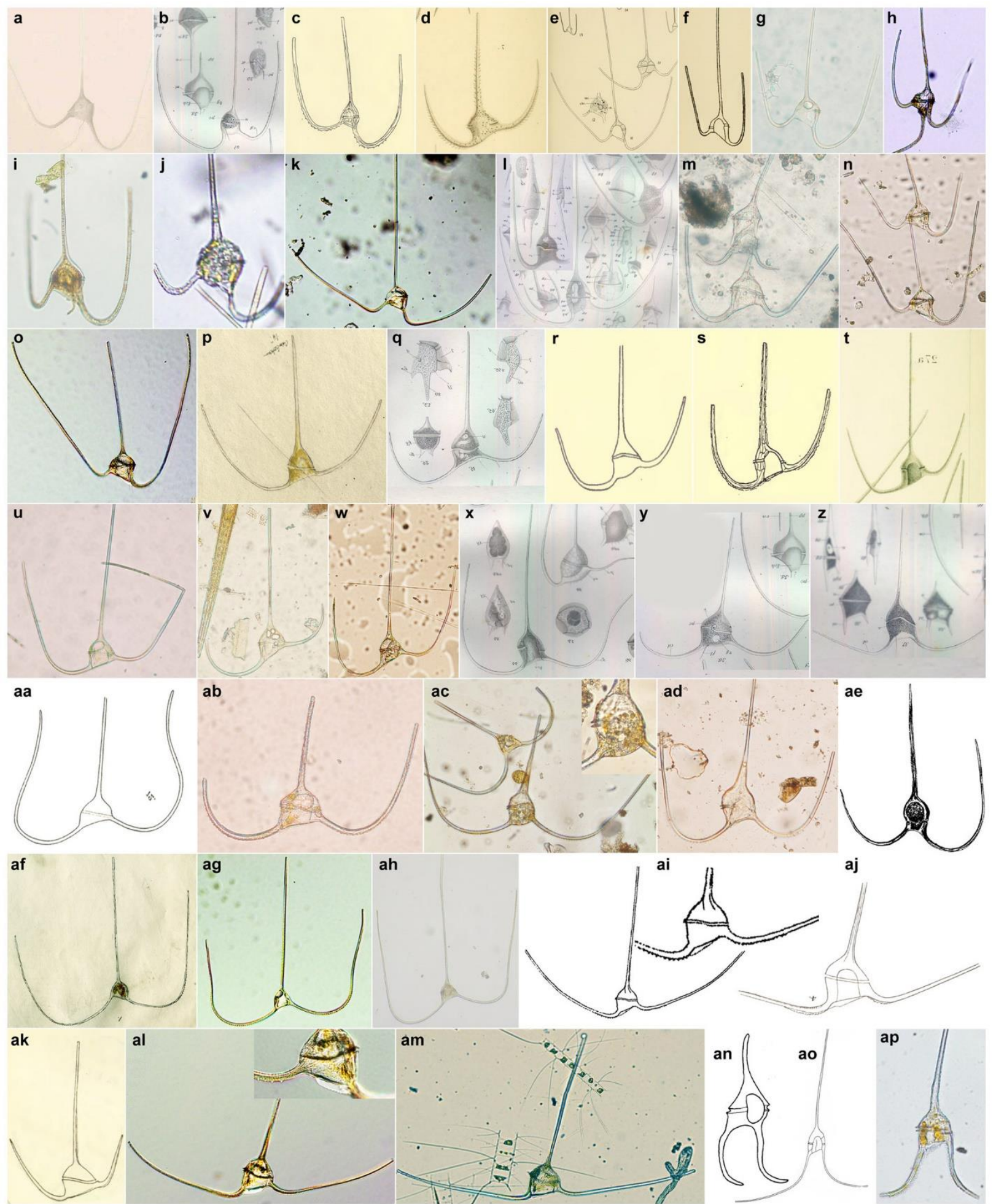

Fig. 9. Line drawings and micrographs of the species of the section Macroceros. $(\mathrm{a}-\mathrm{c}, \mathrm{e}-\mathrm{k})$

Tripos gallicus. (a) Ceratium tripos var. macroceros by Claparède and Lachmann (1859). (b)

C. tripos var. macroceros by Gourret (1883). (c) C. macroceros by Paulsen (1908). (d) C. 


\section{ScienceOpen Preprints}

tripos var. macroceros f. armatum by Karsten (1905). (e) C. gallicum by Kofoid (1907b). (f) C. macroceros deflexum by Kofoid (1907b). (h) Aberrant form. (1-o) T. massiliensis. (1) C. tripos var. massiliense by Gourret (1883). (p-w) T. macroceros. (p) Peridinium macroceros by Ehrenberg. (q) C. tripos var. contrarium by Gourret (1883). (r) C. batavum by Paulsen (1908). (s) C. intermedium by Paulsen (1908). (t) C. tripos var. macroceroides by Karsten (1906). (x-ae) T. carriensis. (x) C. tripos var. inflexum by Gourret (1883). (y) C. tripos var. typicus by Gourret (1883). (z) C. carriense by Gourret (1883). (aa) C. flagelliferum by Cleve (1900). (ac-ad) Cell infected by an endoparasite. (ae) C. ramakrishnae redrawn from Subrahmanyan (1968). (af-ah) T. trichoceros. Peridinium trichoceros by Ehrenberg (1873). (ai) C. carriense by Jørgensen (1920). (aj) C. volans by Cleve (1900). (ak) C. tenue by Ostenfeld and Schmidt (1901). (al-am). T. volans. (an) C. uncinnum redrawn from Sournia (1972). (ao) C. californiense by Kofoid (1907b). (ap) Individual which have undergone autotomy. Scale bars: $50 \mu \mathrm{m}$.

Jørgensen (1920) proposed Ceratium pavillardii for the illustration identified as $C$. vultur by Pavillard (1905) (Fig. 10a-e). This is fortunate because Pavillard (Fig. 10b) showed a cell with scarce postindentation when compared to $C$. vultur (Fig. 10f-g). Tripos pavillardii is more closely related to $T$. volans (Fig. 9aj). The main issue is the synonymy among the tropical taxa T. vultur, T. robustus (Fig. 10h-i), T. japonicus (Fig. 10j-k) and T. sumatranus (Fig. 101-m). Tripos sumatranus and T. recurvus are interpreted as colonial or atypical forms of T. vultur, respectively. Tripos vultur and T. robustus are not considered synonyms because the postindentation is more marked in the latter taxon. Tripos robustus described by Ostenfeld and Schmidt (1901) (Fig. 10h) [non C. robustum (Cleve) Cleve)] is interpreted as individuals 


\section{ScienceOpen Preprints}

of T. japonicus which have undergone autotomy. Tripos reflexus may correspond to an aberrant form (Fig. 10n-o). The section Reflexa is then merged in the section Vultur.

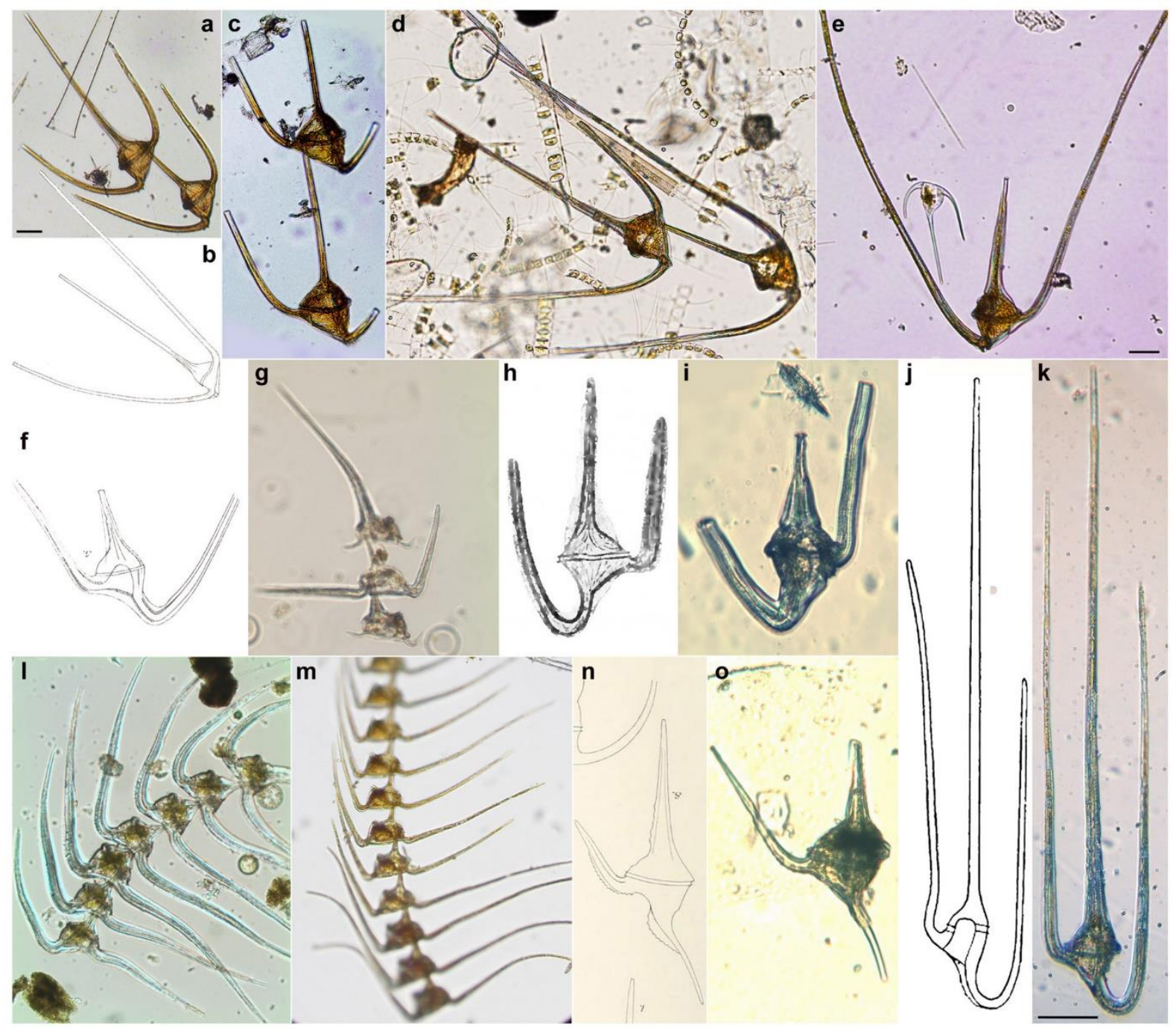

Fig. 10. Line drawings and micrographs of the section Macroceros of the subgenus Tripos. (a-e) Tripos pavillardii. (b) Ceratium vultur by Pavillard (1905). (f-g, l-m) T. vultur. (f) C. vultur by Cleve (1900). (h-k) T. robustus. (h) C. robustum by Ostenfeld and Schmidt (1901). (j) C. japonicum by Schröder (1906). (n-o) T. reflexus. (n) C. reflexum by Cleve (1900). Scale bars: $50 \mu \mathrm{m}$. 


\subsubsection{Subsection Tergestina}

Tripos arcticus (Fig. 11a-d) and T. longipes (Fig. 11e-j) are psychrophilic species cooccurring in arctic-boreal regions. Tripos arcticus was also described as Ceratium labradoricum (Fig. 11b-c). Peridinium arcticum was transferred into Ceratium as C. arcticum (Ehrenberg) Vanhöffen 1897, and not as C. arcticum Vanhöffen 1897 as commonly interpreted in the literature, and C. arcticum (Ehrenberg) Cleve 1900 is a later isonym. Vanhöffen's illustration identified as C. arcticum (Fig. 11e) corresponded to C. longipes. Ceratium longipes was first illustrated as Peridinium tripos by Ehrenberg (1834, pl. 2, figure 1f), later described as $P$. longipes by Bailey (1855) (Fig. 11f) and illustrated as $C$. tripos var. tergestinum by Schütt (1892). The DNA sequences obtained from the strain CCMP1770 have been identified as $T$. longipes. There is an imagen available at https://ncma.bigelow.org/ccmp1770, but it shows an aberrant cell that makes difficult to verify the identification.

\subsubsection{Section Palmata}

Cleve (1897) described C. tripos var. horridum with antapical horns that diverged from the apical horn (Fig. 11h). Based on the original description, C. tripos var. horridum can be considered conspecific with C. longipes (Fig. 11f-g). Other interpretation is that Cleve (1897) illustrated an immature individual, and the antapical horns will be parallel to the apical horn in the mature individuals. Based on the original description, the name $C$. horridum which basionym is $C$. tripos var. horridum is also a synonym of $C$. longipes (I.C.N. art. 7.3). Gran 


\section{ScienceOpen Preprints}

(1902) and other authors reported individuals with antapical horns parallel to the apical horn for C. horridum (Fig. 11p-q), differing from Cleve's basionym. Ceratium intermedium is a name for C. horridum sensu auct. (Fig. $11 \mathrm{k}-1$ ). The original illustration of C. buceros is unfortunate because the shape of the hypotheca is unrealistic, probably reported from an aberrant individual (Fig. 11m-o). Jørgensen (1920) reported as C. buceros (Fig. 11n) a cell with the morphology of $C$. tenue (Fig. 9ak), and he classified C. inclinatum, C. tenuissimum, C. molle and $C$. denticulatum as varieties of $C$. buceros. This is unfortunate due the uncertainties on the identity of C. buceros. Tripos intermedius is common in temperate waters. Ceratium clavigerum, not 'claviger' is recorded in warmer waters. It exhibited long antapical horns, often inflexed (Fig. 11r-s), or with a dilated distal end of the antapical horns (Fig. 11t).

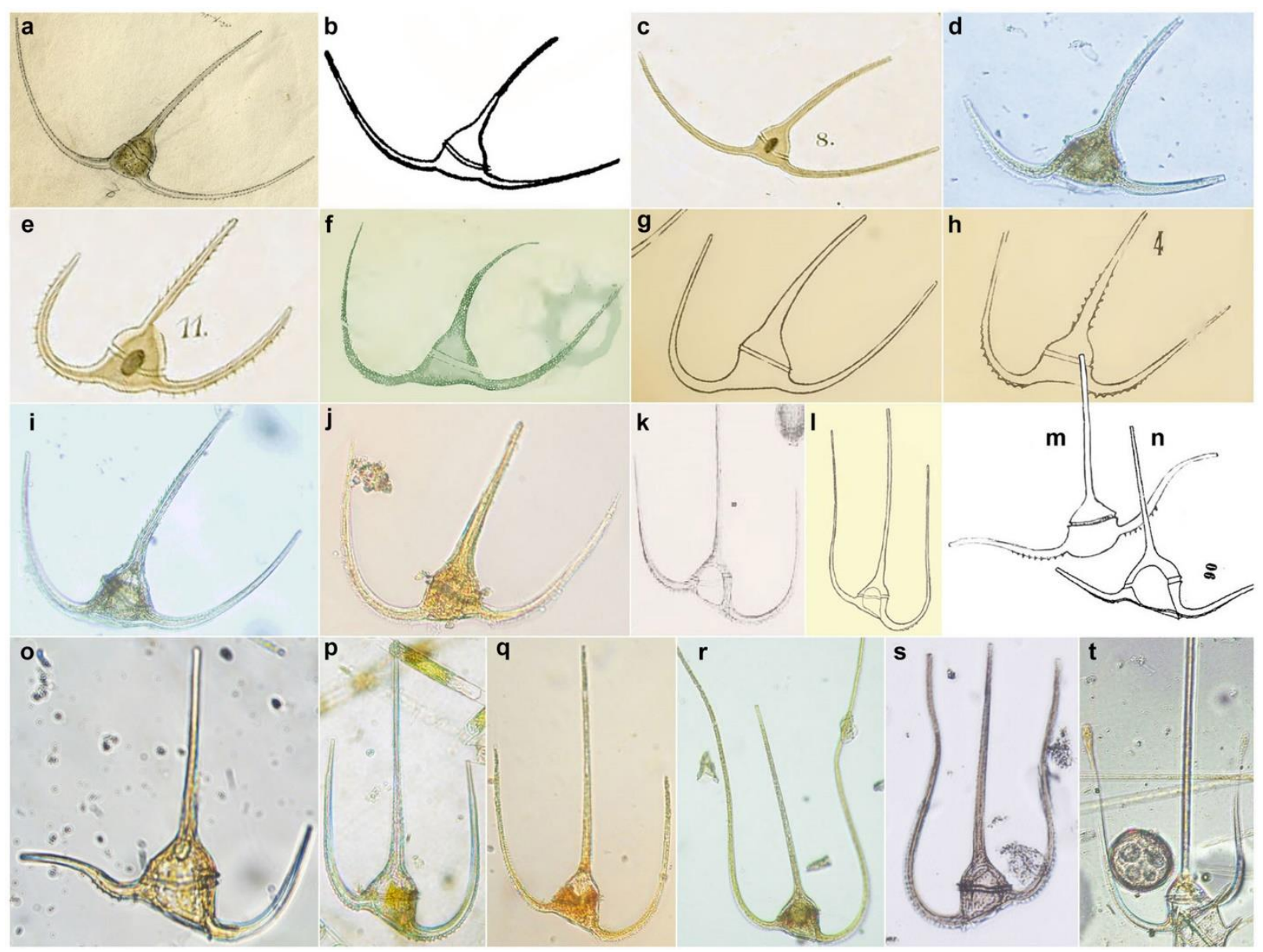




\section{ScienceOpen Preprints}

Fig. 11. Line drawings and micrographs of the species of the section Tergestina $(a-j)$ and section Palmata (k-t). (a-d) Tripos arcticus. (a) Peridinium arcticum by Ehrenberg (1854b). (b) C. tripos var. labradoricum by Schütt (1892). (c) C. labradoricum by Vanhöffen (1897). (e) C. arcticum by Vanhöffen (1897). (f) Peridinium longipes by Bailey (1854). (g) C. tripos var. longipes by Cleve (1897). (h) C. tripos var. horridum by Cleve (1897). (i-j) T. longipes. (k) C. horridum (Cleve) f. intermedium by Jørgensen (1899). (1) C. intermedium f. frigida by Paulsen (1908). (m) C. buceros by Zacharias (1906). (n) C. buceros by Jørgensen (1920). (o) Aberrant cell. (p-q) T. intermedius. (r-t) Tripos clavigerus.

Tripos platycornis is characterized by the flattening of the distal part of the antapical horns which tips are never pointed (Fig. 12a-n). The main controversy in the identification is when the flattening is missing. The cell body of $T$. compressus is similar to T. platycornis, but the pointed tips of the antapical horns of Gran's (1902) original illustration (Fig. 12a) are unreported for T. platycornis (Fig. 12b-n). Authors such as Paulsen (1908) or Balech (1988) have considered $T$. compressus as an independent species, but their illustrations showed blunt tips of the antapical horns as in T. platycornis. These pointed tips of the horns in Gran's illustration is the main obstacle to consider these species as synonyms. A closely related species is $T$. ranipes (Fig. 120-x). Tripos platycornis and T. ranipes are the type species of the sections Platycornia and Palmata, respectively. These sections are here merged with $T$. intermedius ( $=$ C. horridum sensu auct.) and $T$. clavigerus in a single section, and Palmata is the earlier available name.

\subsubsection{Section Reticulata}




\section{ScienceOpen Preprints}

The SSU rRNA gene sequence of Tripos hexacanthus clustered as an independent lineage that could be a link between the section Macroceros and other sections of the subgenus Tripos (Fig. 2). It is difficult to find relatives for T. hexacanthus. This is a peculiar species by characterized with strong surface reticulation of the theca and twisted antapical horns (Fig. $12 \mathrm{y}-\mathrm{ab})$.

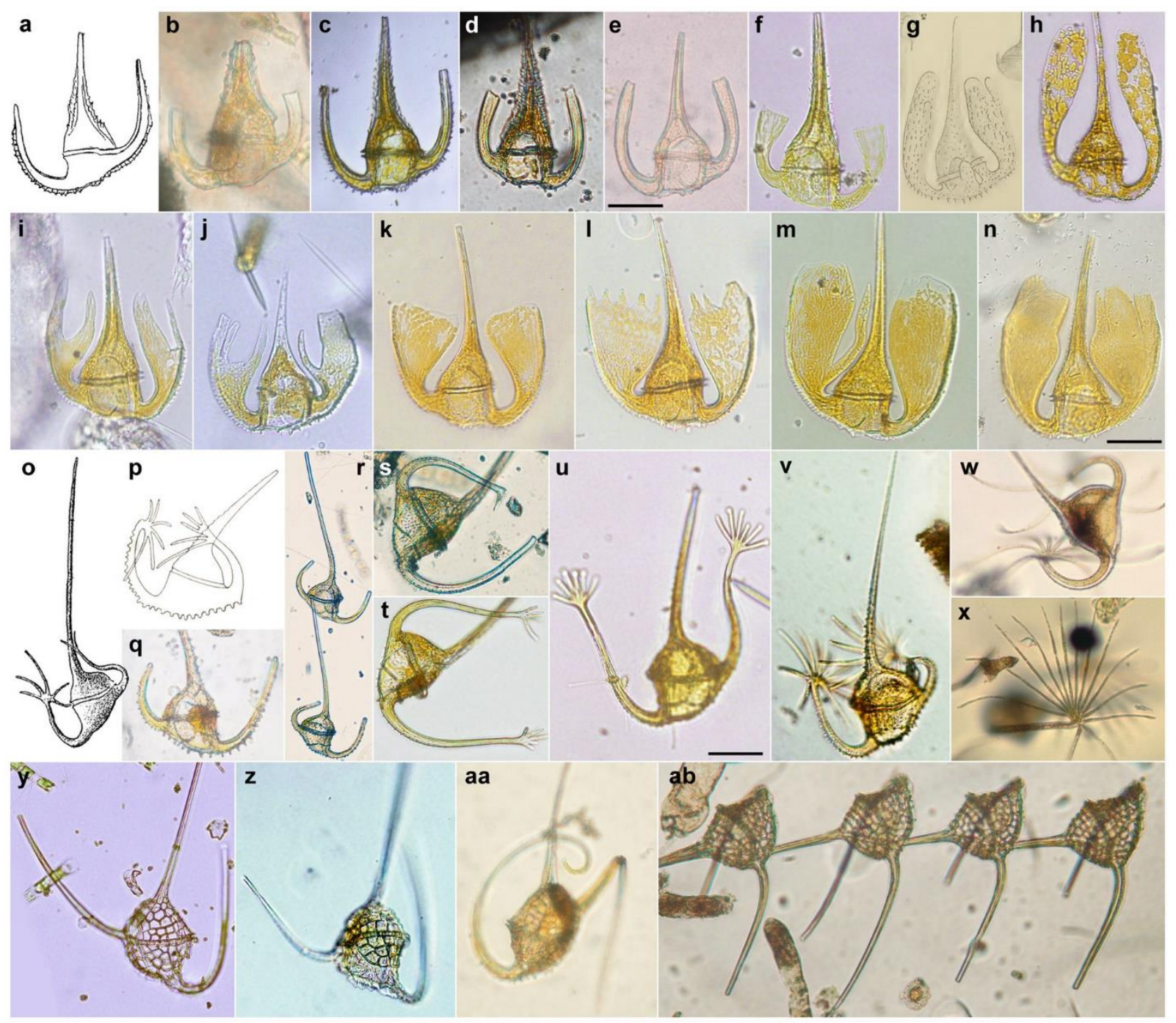

Fig. 12. Line drawings and micrographs of the specie of the section Palmata, including Platycornia. (a) Ceratium compressum by Gran (1902). (b-m). Tripos platycornis. (g) C. platycorne by Daday (1888). (o-x) Tripos ranipes. (o) Ceratium sp. by Schütt (1882). (p) C. ranipes by Cleve (1900). (y-ab) Tripos hexancanthus. Scale bars: $50 \mu \mathrm{m}$. 


\subsubsection{Section Tripos (=Rotunda)}

The type species of Tripos, T. muelleri, and allied taxa show the typical anchor-like shape lacking the postindentation in the posterior contour (Fig. 13a-e). The species are distinguished based on the relative length and orientation of the antapical horns. When the antapical horns are short, it is not easy to decide whether the morphology is due to autotomy, an immature cell, seasonal variant or a true distinct species. Examples are T. brevis, T. pulchellus, T. schmidtii among others (Fig. 13f-i). This variability is a nightmare for the species circumscription, but it is interesting from the ecological point of view as it could be interpreted as responses to the environmental conditions. An example is T. egyptiacus that was described from the Canal of Suez (Fig. 13j). This is not an endemism because the Canal was inaugurated in 1869 and there is no time for the evolution of a new species. Then, the extreme and fluctuant environmental conditions (temperature, salinity) in the Canal of Suez induce an anomalous configuration of the antapical horns. The variable morphology of $C$. egyptiacum could correspond to stressed individuals of T. muelleri or even T. dens, the latter first described from the Red Sea (Fig. 13k). Even more problematic is when the antapical horns are very short or almost absent as observed in T. dens (Fig. 13k) and T. divaricatus (Fig. 13m). Böhm (1931) already reported the morphological variability of $T$. dens, including the example of a heteromorphic chain (Fig. 131). One of the daughter cells corresponded to the morphology recently described as $T$. balechii (Fig. 13o). Lemmermann (1899, p. 345) proposed C. tripos var. divaricatum citing a basionym an illustration by Bergh (1881). That individual from the 


\section{ScienceOpen Preprints}

Baltic Sea showed the anterior-most daughter cell of T. muelleri with an incomplete hypotheca (Fig. 13m). Based on observations near the USA-Mexico border, Kofoid (1908c) ranked $C$. tripos var. divaricatum at the species level and he figured a high intraspecific morphological variability (Fig. 13n). The immature cell of T. muelleri from the cold Baltic Sea (Fig. 13m) is not conspecific with Kofoid's taxon from the subtropical Pacific (Fig. 13n). The species name C. divaricatum is a synonym of T. muelleri (I.C.N. article 7.3) and Kofoid's taxon needs other name that could be $T$. dens or T. balechii, the latter described from the Mexican Pacific in 2003 (Fig. 13o, Meave del Castillo et al., 2003). The molecular data should solve whether $T$. dens and T. balechii are or are not conspecific. There are several DNA sequences identified as $T$. balechii from the Mexican Pacific (Figs 1,2), and a single DNA sequence identified as T. dens from Mexico (accession number MF927978). Anomalously, this sequence is full of indeterminate nucleotides that make impossible the comparison. With the current knowledge, T. dens is the correct name for this highly polymorphic taxon from warm oceans (Fig. 13j-p). 


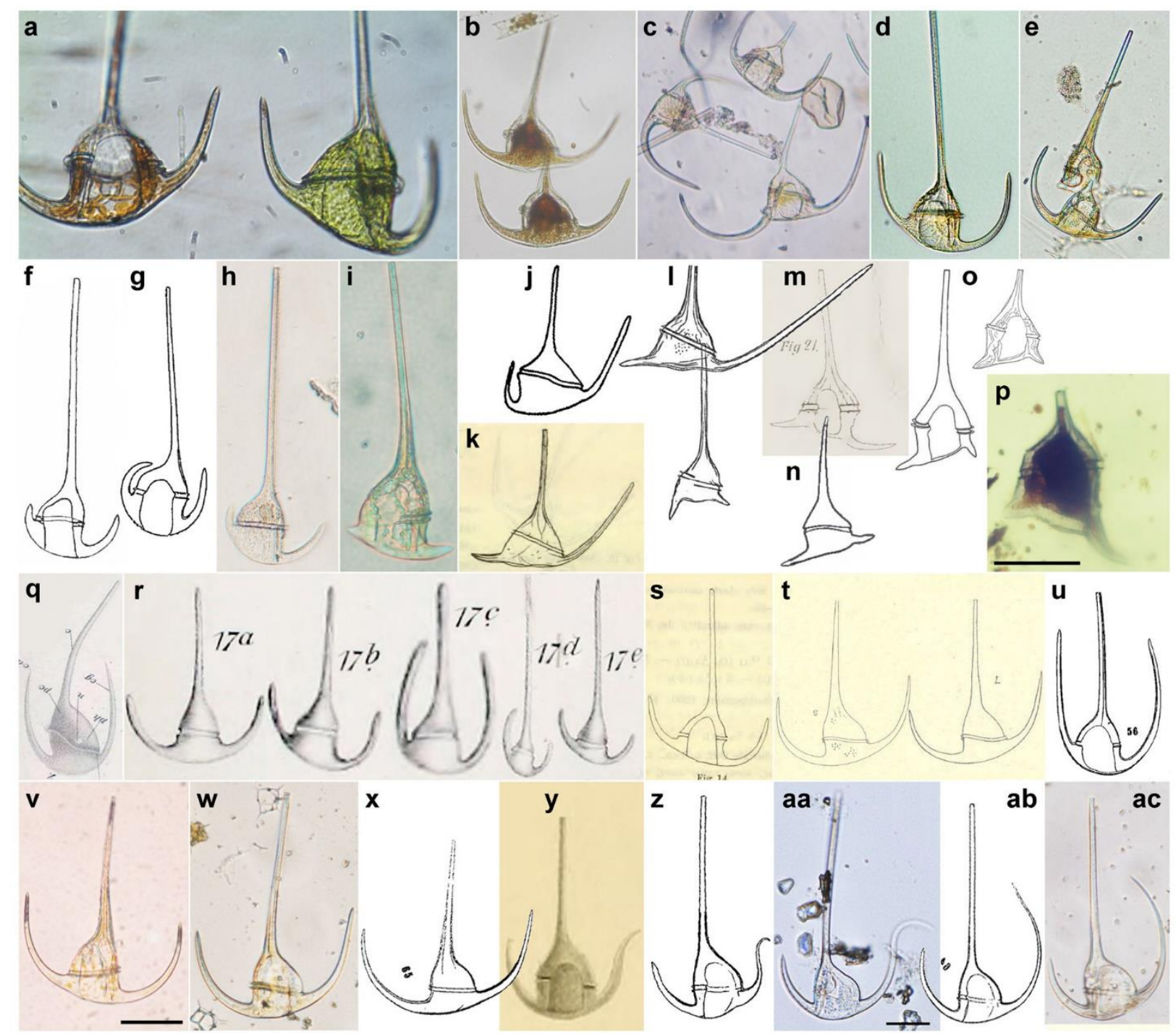

Fig. 13. Line drawings and micrographs of species of the section Tripos. (a-e) T. muelleri. (a) Note the different coloration. (f) C. pulchellum by Schröder (1906). (g) C. schmidtii redrawn from Jørgensen (1911). (h-i) T. pulchellus. (j) C. egypticum redrawn from Halim (1963). (k) C. dens by Ostenfeld and Schmidt (1901). (1) Heteromorphic chain of C. dens redrawn Böhm (1931). (m) A variety of C. tripos by Bergh (1881). (n) C. divaricatum by Kofoid (1908c). (o) C. balechii redrawn from Meave del Castillo et al. (2003). (p) Tentatively T. dens. (q) C. tripos var. gracile by Gourret (1883). (r) C. tripos var. gracile by Schröder (1906). (s) C. tripos var. gracile by Ostenfeld and Schmidt (1901). (t) C. tripos by Pavillard (1905) = C. gracile in Pavillard (1907a). (u) C. gracile by Jørgensen (1920). (v-w, aa, ac) T. gracilis. (x) C. 


\section{ScienceOpen Preprints}

declinatum f. majus by Jørgensen (1920). (y) C. declinatum by Karsten (1907). (z) $C$. declinatum var. debile by Jørgensen (1920). (ab) C. declinatum f. brachiatum by Jørgensen (1920).

Some of the earlier illustrations of new species were too sketchy or were unprecise to represent the real morphology of the species. The illustration of Ceratium tripos var. gracile by Gourret (1883) was unfortunate. Gourret showed a cell with a bent apical horn that is atypical for the members of this section, and the midbody was anomalously elongated along the anterior-posterior axis. An important feature is that the apical horn arose close to the left side of the body and the left side of the epitheca is less convex (Fig. 13q). Gourret (1883) described $C$. tripos var. gracile, and he cited $C$. tripos var. gracile Pouchet as synonym. Then, C. tripos var. gracile Gourret is an invalid name because it is a later isonym. The description of $C$. tripos var. gracile by Pouchet (1883) did not include illustration, and he only reported that the cell showed long and thin double-curved horns. This suggests that it is unrelated to Gourret's taxon. Pavillard (1905) proposed the new species name $C$. gracile without apparently illustration. He reported that the species corresponded to $C$. tripos var. gracilis by Schröder (1900, his figures 17b,d,e) (Fig. 13r), and Ostenfeld and Schmidt (1901) (Fig. 13s). The illustration by Ostenfeld and Schmidt (1901) is close to C. tripos. Later, Pavillard (1907a) reported that the figures 5 and 7 in Pavillard (1905) (Fig. 13t) and Gourret's C. tripos var. gracile (Fig. 13q) corresponded to $C$. gracile. These illustrations showed the apical horn arising close to the left side of the midbody. Karsten (1907) described C. tripos declinatum with individuals showing a distinctive loop in the longer left antapical horn (Fig. 13y). Karsten (1907) illustrated the apical horn arising from the middle of the epitheca (Fig. 13y), but it arose closer to the left side in that species (Fig. 13aa). A long left antapical horn with a distal 


\section{ScienceOpen Preprints}

loop is typically observed in oceanic individuals (Fig. 13aa). Ceratium gracile Pavillard 1905 and 'C. tripos declinatum Karsten n. sp. 1907' are synonyms. In this study, C. gracile Pavillard 1905 (Fig. 13t, u-w, aa, ac) is revived because it has the priority over C. declinatum (Fig. 13y). Jørgensen $(1911,1920)$ proposed $C$. gracile (Gourret) Jørgensen interpreting that $C$. tripos var. gracile was Pavillard's C. coarctatum and C. symmetricum (Fig. 14a-d). Jørgensen (1920) proposed the new varieties $C$. gracile var. coarctatum and $C$. gracile var. symmetricum for the two species described by Pavillard (1905). Jørgensen's illustration (Fig. 13u) under the name $C$. gracile corresponded to $C$. coarctatum (Fig. 14a-b). Ceratium gracile (Gourret) Jørgensen is a later isonym of $C$. gracile Pavillard. Ceratium gracile showed an asymmetric epitheca with the apical horn arising close to the left side, while the epithecae of $C$. symmetricum and $C$. coarctatum are symmetric with the apical horn arising from the middle (Fig. 14a-d). Jørgensen (1920) proposed the infraspecific taxa C. declinatum f. majus (Fig. 13x), C. declinatum f. brachiatum (Fig. 13ab), and C. declinatum var. debile (Fig. 13z). Ceratium declinatum f. majus and $C$. declinatum var. debile were unnecessary varieties because they fit well with the original descriptions of $C$. gracile (Fig. 13t) and C. tripos var. declinatum (Fig. 13y), respectively. Ceratium declinatus f. brachiatum strongly resemble to Jørgensen’s C. euarcuatum (Fig. 14i). 


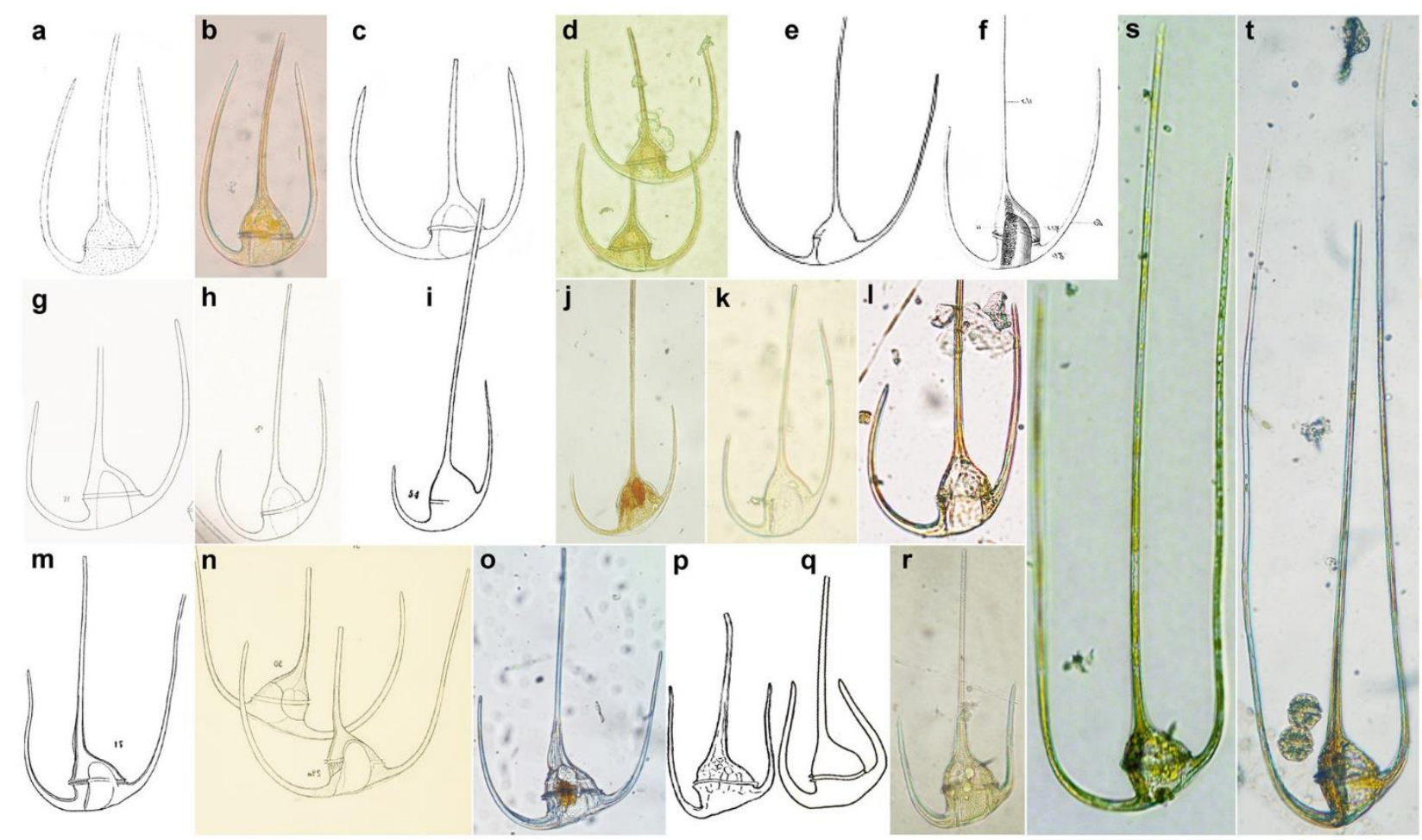

Fig. 14. Line drawings and micrographs of species of the section Limulus of the subgenus Tripos. (a) Ceratium coarctatus by Pavillard (1905). (b) Tripos coarctatus. (c) C. symmetricum by Pavillard (1905). (d) T. symmetricus. (e) C. filicorne by Steemann Nielsen (1934). (f) C. tripos var. arcuatum by Gourret (1883). (g) C. arcuatum by Cleve (1900). (h) C. arcuatum by Pavillard (1905). (i) C. euarcuatum by Jørgensen (1920). (j-1) T. arctuatus. M. C. karstenii by Pavillard (1907a). (n) C. schrankii by Kofoid (1907b). (o) T. karstenii. (p) C. tripos var. hiemale by Paulsen (1908). (q) C. aultii redrawn from Graham and Bronikovsky (1944). (r) T. aultii. (s-t). T. longissimus.

\subsubsection{Section Limulus}

The resolution of the SSU rRNA gene phylogeny is insufficient to resolve the divergence among the species of the subgenus Tripos (Fig. 2), and the LSU rRNA gene phylogeny only 


\section{ScienceOpen Preprints}

contains sequences of three species of the section Tripos (T. muelleri, T. brevis and T. balechii) that clusters together with moderate support (Fig. 1). The strain CCMP1770 identified as $T$. longipes is the only strain with sequences in both SSU- and LSU rRNA gene phylogenies. Independently of the correct species identification, the LSU rRNA gene sequence of the strain CCMP1770 is distantly related to the clade of the section Tripos. In the SSU rRNA gene phylogeny, the sequence of the strain CCMP1770 clusters with three species with similar morphology retrieved as $T$. symmetricus, $T$. arietinus and $T$. euarcuatus, and more distantly related to representatives of the section Tripos (Fig. 2). This suggests that these three species should not be classified in the section Tripos, and the classification in the section Limulus appears as the first choice.

Tripos symmetricus (Fig. 14a-b) and T. coarctatus (Fig. 14c-d) are classified in the section Limulus, and more distantly related to $T$. gracilis (=C. declinatum auct. mult.). Tripos filicornis (Fig. 14e) exhibited intermediate characteristics between $T$. symmetricus and $T$. arcuatus. As occurred with C. gracile, the name C. arcuatum (Gourret) Cleve has disappeared in the literature. Gourret (1883) described C. tripos var. arcuatum (Fig. 12f), and Cleve (1900) under the name C. arcuatum illustrated a cell (Fig. 14g) that differed from Gourret's taxon. Cleve (1900, p. 13) cited Gourret's taxon as basionym, and even if Cleve's illustration corresponds to a distinct species, C. arcuatum is the Gourret's taxon at the species rank (I.C.N. article 7.3). Pavillard (1905) illustrated C. arcuatum (Fig. 14h) as similar to Gourret's taxon (Fig. 14f). Jørgensen (1920) noted Cleve and Gourret illustrated distinct species. However, instead to propose a new species name for Cleve’s species, Jørgensen (1920) proposed $C$. euarcuatum for "this characteristic species as already detected by Gourret 1883 (pl. 2, fig. 42, C. tripos var. arcuatum)". Jørgensen was citing the same basionym for C. arcuatum and $C$. euarcuatum, then these species names are synonyms (I.C.N. article 7.3). What is the name for 


\section{ScienceOpen Preprints}

C. arcuatum sensu Cleve? Pavillard (1905, p. 51) noted that C. arcuatum sensu Cleve was distinct from the Gourret's taxon. Later Pavillard (1907a) proposed the species name $C$. karstenii (Fig. 14m) citing that it corresponded C. arcuatum sensu Cleve. That year, Kofoid (1907b) proposed C. schrankii (Fig. 14n) that is conspecific, although he did not cite Cleve's C. arcuatum. Pavillard published $C$. karstenii three weeks before than Kofoid's taxon. Then, the names for Gourret's and Cleve's taxa are T. arcuatus (三T. euarcuatus) (Fig. 14j-1) and T. karstenii (Fig. 14o) (=T. schrankii), respectively. A taxon related to T. karstenii is T. muelleri var. hiemale (Fig. 14p). It has not been ranked at the species level, and it is doubtful its assignation as variety of T. muelleri. It is here considered conspecific with T. aultii (Fig. 14qr). Other closely related taxon is $T$. longissimum which long antapical horns are directed parallel to the apical one (Fig. 14s-t).

Cleve (1900) described Ceratium arietinum (Fig. 15a) that is closely related to species such as Tripos symmetricus and T. arcuatus. Ceratium tripos f. heterocamptum (Fig. 15b) and C. bucephalum (Fig. 15c) are synonyms of T. arietinus, although the distinctive bent of the right apical horn is less evident (Fig. 15e-g). Graham and Bronikovsky (1944) described $C$. carnegiei with an inflated midbody (Fig. 15d). It cannot be discarded that it corresponds to individuals of $T$. arietinus infected by an endoparasite. Gómez et al. (2008) reported micrographs of an individual identified as $C$. carnegiei, but it corresponded to $C$. ramakrishnae (Fig. 9ae) that is a cell of $C$. carriense (non $C$. carriense auct. mult.) infected by an endoparasite (Fig. 9ac-ad). Tripos lunula is a thermophilic colony-forming species, with a semicircular contour of the antapical horns (Fig. $15 \mathrm{~h}-\mathrm{j}$ ). Taxa of easy identification are $T$. paradoxides (Fig. 15k-p) and T. limulus (Fig. 15q-w). In contrast, it is difficult to solve whether T. azoricus (Fig. 15x-z) and T. petersii (Fig. 15aa-ae) are or are not conspecific. The section Limulus is here enlarged to include T. arcuatus, T. arietinus, T. aultii, T. azoricus, $T$. 


\section{ScienceOpen Preprints}

carnegiei, T. coarctatus, T. limulus, T. longissimus, T. lunula, T. karstenii, T. paradoxides, $T$. petersii, T. subcontortus (non T. contortus) and T. symmetricus.
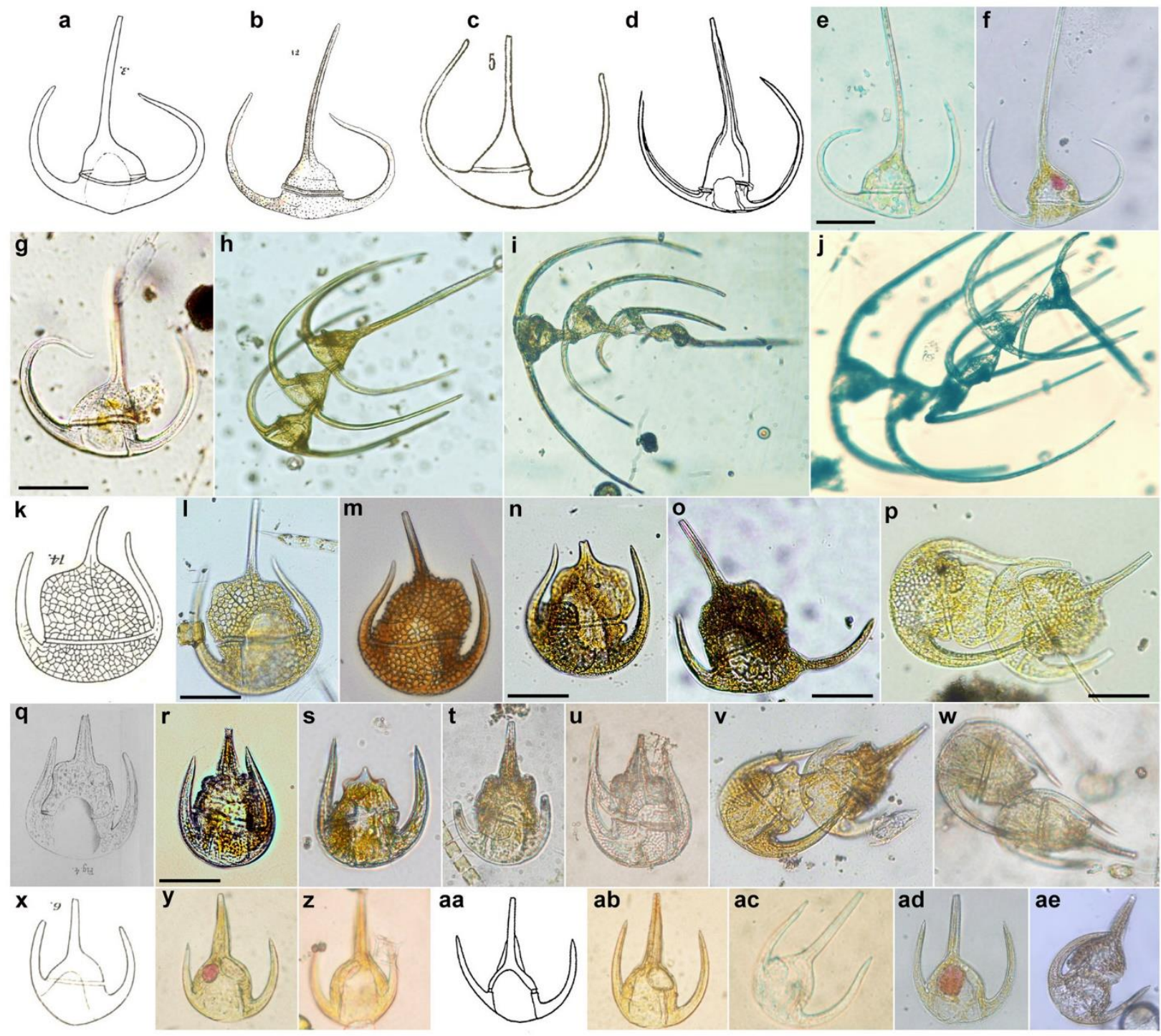

Fig. 15. Line drawings and micrographs of members of the section Limulus. (a) Ceratium arietinum by Cleve (1900). (b) C. tripos f. heterocamptum by Jørgensen (1899). (c) C. tripos var. bucephalum by Cleve (1897). (d) C. carnegiei redrawn by Graham and Bronikovsky (1944). (e-g) Tripos arietinus. (h-j) T. lunula. (k-p) T. paradoxides. (k) C. paradoxides by Cleve (1900). (q-w) T. limulus. (q) C. tripos var. limulus by Pouchet (1883). (x-ab) T. 
azoricus. (x) C. azoricus by Cleve (1900). (aa) C. petersii by Steemann Nielsen (1934). Scale bars: $50 \mu \mathrm{m}$.

\subsubsection{Subsection Gibbera}

As occurred with T. hexacanthus classified in its own section, T. gibberum (not 'gibberus') is other species with atypical configuration of the antapical horns that makes difficult to find affinities with other taxa. The midbody is wide and the right antapical horn is bent and crossing the apical horn (Fig. 16a-d, i-m). Tripos gibberum is classified as the only member of its subsection. The available molecular data, retrieved as T. concilians, do not show any supported relationship with other species (Fig. 2). Tripos gibberum is morphologically close to the members of section Tripos because the posterior body margin is rounded, but the antapical horns are deflected with distinct lengths. Gourret (1883) described C. gibberum (Fig. 16a), C. gibberum var. sinistrum (Fig. 16c), and C. gibberum var. contortum (Fig. 16b). Ceratium curvicorne (Fig. 16e) resembled the anterior-most daughter cell of $C$. gibberum (Fig. 16i-j). Cleve (1900) proposed C. contortum for C. gibberum var. contortum that was illustrated in Gourret's figure 33. Jørgensen (1920, p. 72) proposed C. concilians (Fig. 16f) for “C. tripos var. contortum, Gourret 1883, plate 2, fig. 33)”, but Gourret's figure 33 is labelled as $C$. gibberum var. contortum (Fig. 16b). Independently of whether $C$. contortum sensu Cleve and C. concilians are or are not taxonomical (heterotypic) synonyms, these two species are homotypic (nomenclatural) synonyms that share the same basionym. Steidinger and Tangen (1997, p. 474) reported for T. gibberum: "can be confused with $C$. concilians which has proximally bent apical horn and rounded right epithecal shoulder. $C$. concilians is less reticulate". Observations of the cell division of T. gibberum suggest that 


\section{ScienceOpen Preprints}

reticulation or the bent of the apical horn have little diagnostic value because it depends on the degree of maturation of the cell (Fig. 16i-m). The illustration of $C$. gibberum var. contortum by Gourret (1883) suggests that it is a morphotype of T. gibberus, and consequently T. contortus is a synonym (I.C.N. art. 7.3). Ceratium contortum sensu Cleve (Fig. 16g), already illustrated by Schütt (1892) (Fig. 16h), and C. gibberum var. contortum differed in several aspects. The difference in the apical horn is irrelevant because Gourret illustrated unrealistic tilted apical horns as he did for C. tripos var. gracile (Fig. 13q). The apical horn of C. gibberum var. contortum arouse from the middle of the epitheca (Fig. 16b), while in $C$. contortum sensu Cleve arouse from the left side (Fig. 16g). Cleve's illustration showed a cell with a straight proximal part of the right antapical horn (Fig. 16g), while it is bent since the proximal part in Gourret's taxon (Fig. 16b). All the varieties of C. gibberum are neritic forms and common in the coast of Marseille, but the species misidentified as C. contortum has preferentially an oceanic and tropical distribution. I have observed it in the open Pacific (Fig. 16r-s), but not in the coasts of Marseilles. Ceratium contortum sensu Cleve needs other species name. Certainly, C. contortum sensu Cleve is close to $C$. karstenii, but the proposal of C. contortum var. karstenii (Pavillard) Sournia is unfortunate because C. contortum sensu Gourret is not closely related to $C$. karstenii. The available names for Cleve's $C$. contortum are C. subcontortus (Fig. 16n) and C. saltans (Fig. 16o) by Schröder (1906), or C. longinum (Fig. 16p) by Karsten (1906). Beyond the discussion on the priority of the publication, the illustration of $C$. longinum (Fig. 16p) does not fit well C. contortum sensu Cleve (Fig. 16g). The records reported in the warm waters as $T$. contortus are usually Cleve's taxon and they should be referred as T. subcontortus (Fig. 16r-s). Steidinger and Tangen (1997, p. 472) reported $C$. arcuatum (Gourret) Cleve as a posterior synonym of $C$. contortum (Gourret) Cleve. The comparison of the basionym's original illustrations evidences that they are 


\section{ScienceOpen Preprints}

independent species (Figs 14f, 16b). Tripos gibberum (Fig. 16i-m), T. contortus, T. curvicornis and T. concilians are different names for a single species and classified in own subsection with affinities to the sections Tripos and Limulus. Tripos subcontortus is classified in the section Limulus. The figure 17 reports a tentative evolutionary scheme of the family Ceratiaceae.

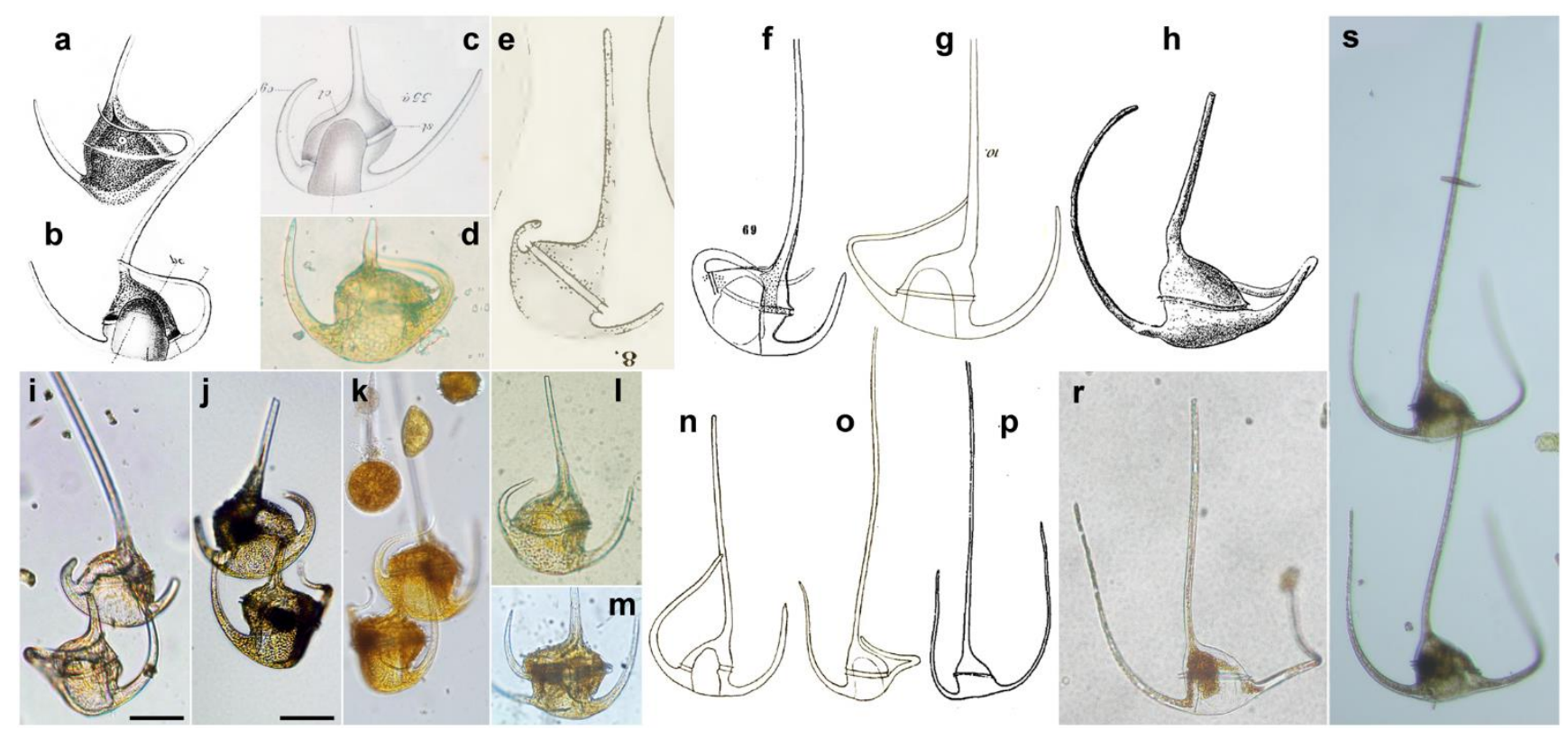

Fig. 16. Line drawings and micrographs of species of the subsection Gibbera, and $T$. subcontortus of the section Limulus. (a) Ceratium giberrum var. sinistrum by Gourret (1883). (b) C. gibberum var. contortum by Gourret (1883). (c) C. gibberum. (d, i-m) Tripos gibberum. (e) C. curvicorne by Daday (1888). (f) C. concilians by Jørgensen (1920). (g) C. contortum by Cleve (1900). (h) Ceratium sp. by Schütt (1892). (n-o) C. subcontortum and C. saltans by Schröder (1906). (p) C. tripos var. longinum by Karsten (1906). (r-s) T. subcontortus. Scale bars: $50 \mu \mathrm{m}$. 


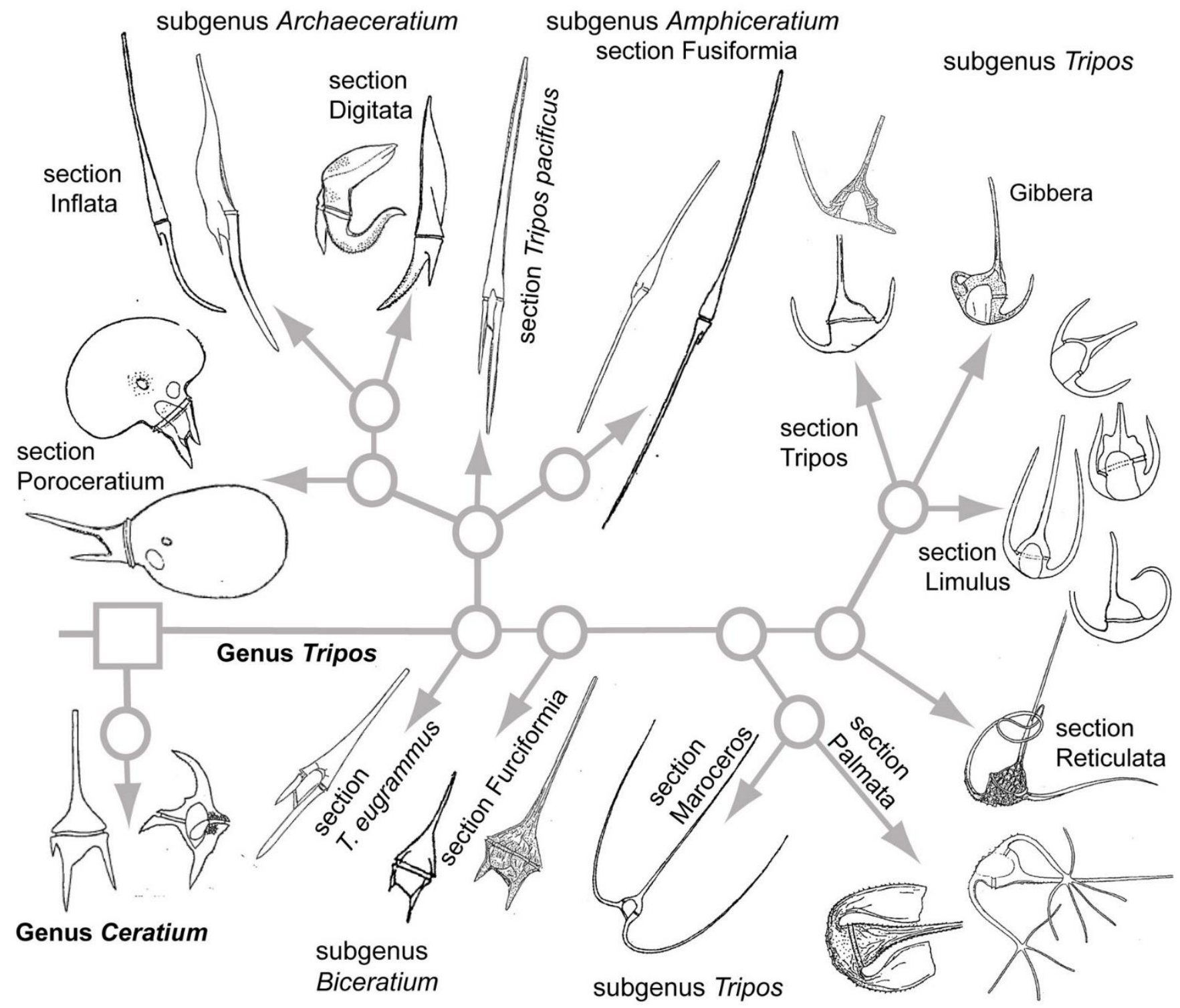

Fig. 17. Tentative evolutionary scheme of the family Ceratiaceae.

\subsection{List of correct species}

About 165 species names of marine species of Ceratium have been proposed. Numerous species (i.e., Tripos muelleri) have tens of described varieties and forms and the genus accounted for a total of about 800 infraspecific taxa. The diagnostic criteria for the species identification such as the relative length and orientation of the antapical horns varies according 


\section{ScienceOpen Preprints}

the cell maturation, autotomy and environmental conditions. There are studies on the sexual life cycle of the freshwater Ceratium, but very few on Tripos (Apstein, 1911). The nature of the gametes will be useful to solve the controversy in the identity of species with short antapical horns such as $T$. lineatus and T. minutus, and the infraspecific taxa of T. muelleri (Lohmann 1908). The cultures will help investigate the intraspecific variability, but aberrant forms are often observed in culture conditions, and they should not be confused with 'natural' life stages.

We are far to solve the speciation of Tripos based on molecular data with sequences of only 30 and 9 species in the SSU- and LSU rDNA phylogenies, respectively. The species circumscription can be resolved with the sequences of the complete rDNA gene, including more variable regions (i.e., ITS). Currently, there are ITS sequences of only 3 species. For example, there is no a complete of the SSU rDNA sequence of T. muelleri, one of the first described dinoflagellates and abundant next door of the specialized laboratories in molecular phylogeny. The melting of Arctic sea ice has increased the research interest in the region. However, a documented DNA sequence of T. arcticus is not available. We cannot expect significant advances in a near future, especially for the tropical and deep water species, that are essential to understand the evolution of Tripos.

Tripos is the dinoflagellate genus with more infraspecific taxa, with species with several varieties, and these varieties with several forms. Each author will decide to use a given variety or form, and Gómez (2013) transferred all the species and infraspecific taxa of the marine Ceratium into Tripos. However, the publication of these alternative names in single publication invalidate all the new combinations (I.C.N., art. 36.3). Some of new combinations of Tripos at the species rank are here proposed again. A species list with the correct species names and their synonyms is below proposed. 
Genus Tripos Bory 1823 (Bursaria O.F. Müller 1773 in part, Ceratium Schrank 1793 in part, Cercaria Michaelis 1830 in part, Ceratophorus Diesing 1850 in part, Peridinium Ehrenberg 1833 in part, Dimastigoaulax Diesing 1866 in part, Amphiceratium Vanhöffen 1896, Biceratium Vanhöffen 1896, Poroceratium Vanhöffen 1896, Euceratium (Gran 1902) Ostelfeld 1903, Neoceratium F.Gómez, D.Moreira et P.López-García, nom. illegit.

Subgenus Biceratium (Vanhöffen 1896) Jørgensen 1911, genus Biceratium Vanhöffen, subgenus Orthoceratium Meunier 1919 (non Schrank 1803, nec Sournia 1968).

\section{Section of Tripos eugrammus}

Tripos eugrammus (Ehrenberg 1860) F.Gómez, comb. nov. Basionym: Peridinium eugrammum Ehrenberg 1860, Monatsber. K. Akad. Wiss. Berlin 1859: 792. Synonyms: Ceratium eugrammum (Ehrenberg) W.S.Kent 1881, C. biceps Claparède et J.Lachmann 1859 (non C. biceps sensu Kofoid 1908c), non Tripos furca auct. mult.

Sectio Furca Pavillard 1907b, sectio Furciformia Jørgensen 1911, sectio Biceratium (Vanhöffen 1896) Gran 1902, including sectio Pentagona Jørgensen 1920.

Subsectio Eufurca Jørgensen 1911

Tripos furca (Ehrenberg 1833) F.Gómez 2013. Synonyms: Peridinium furca Ehrenberg, C. furca (Ehrenberg) Claparède et J.Lachmann 1859, Biceratium furca (Ehrenberg) Vanhöffen 1897, B. debile Vanhöffen 1897, non Tripos eugrammus auct. mult. 
Tripos hircus (Schröder 1909) F.Gómez, comb. nov. Basionym: Ceratium hircus Schröder 1909, Ber. Deutsch. Bot. Ges. 27: 213, fig. 2.

Tripos lineatus (Ehrenberg 1854) F.Gómez 2013, comb. nov. Basionym: Peridinium lineatum Ehrenberg 1854. Ber. K. Akad. Wiss. Berlin 1854: 240 (三C. lineatum (Ehrenberg) Cleve 1899, Biceratium lineatum (Ehrenberg) S.T.Moses 1929).

Subsectio Pentagona Jørgensen 1911

Tripos minutus (Jørgensen 1920) F.Gómez 2013 (三C. minutum Jørgensen 1920).

Tripos pentagonus (Gourret 1883) F.Gómez, comb. nov. Basionym: Ceratium pentagonum Gourret 1883. Ann. Mus. Hist. Nat. Marseille 1(8): 45, pl. 4, fig. 5. Synonym: C. subrobustum (Jørgensen 1920) Steemann Nielsen 1934, C. lineatum auct. mult.

Tripos setaceus (Jørgensen 1911) F.Gómez 2013. Synonyms: C. setaceum Jørgensen 1911, C. kofoidii Jørgensen 1911, C. boehmii H.W.Graham et Bronikovsky 1944.

Tripos teres (Kofoid 1907b) F.Gómez 2013 (三C. teres Kofoid)

Sectio Candelabra Jørgensen 1911

Tripos candelabrum (Ehrenberg 1859a) F.Gómez 2013. Synonyms: P. candelabrum Ehrenberg 1859a, C. candelabrum (Ehrenberg) F.Stein 1883, C. depressum Gourret 1883, C. obliquum Gourret 1883, C. globatum Gourret 1883, C. allieri Gourret 1883, C. dilatatum Gourret 1883 [non C. dilatatum (G.Karsten 1905) Kofoid 1907a]. 
Subgenus Archaeceratium Jørgensen 1920, subgenus Poroceratium (Vanhöffen) Jørgensen 1911, genus Poroceratium Vanhöffen 1896.

Sectio Poroceratium (Vanhöffen 1896) Jørgensen 1911, subsectio Annulifera Jørgensen 1920.

Tripos gravidus (Gourret 1883) F.Gómez 2013. Synonyms: C. gravidum Gourret, C. oviforme Daday 1888, C. praelongum (Lemmermann 1900) Kofoid 1907 ex Jørgensen 1911, Poroceratium gravidum (Gourret) Vanhöffen 1896.

Tripos cephalotus (Lemmermann 1899) F.Gómez, comb. nov. Basionym: Ceratium gravidum var. cephalotum Lemmermann 1899. Abh. Naturw. Ver. Bremen 16: 349, pl. 1, fig. 16. Synonym: C. cephalotum (Lemmermann) Jørgensen 1911.

\section{Sectio Lanceolata Jørgensen 1911}

Tripos lanceolatus (Kofoid 1907a) F.Gómez 2013 (三C. lanceolatum Kofoid).

Sectio Digitata Jørgensen 1911, subsectio Beloniformia Jørgensen 1911, subsectio Incisa Jørgensen 1911.

Tripos belone (Cleve 1900) F.Gómez, comb. nov. Basionym: Ceratium belone Cleve 1900, K. Svenska Vet.-Akad. Handl., [ser. 4] 34(1): 13, pl. 7, fig. 13. Synonym: C. incisum (G.Karsten 1906) Jørgensen 1911, non C. pacificum Schröder 1906. 
Tripos brunellii (Rampi 1942) F.Gómez 2013 (三C. brunellii Rampi).

Tripos digitatus (F.Schütt 1895) F.Gómez 2013 (三C. digitatum F.Schütt).

Tripos rotundatus (Jørgensen 1920) F.Gómez, comb. nov. Basionym: Ceratium digitatum var. rotundatum Jørgensen 1920. Rep. Dan. Oceanogr. Exped. 1908-10 2(J.1): 7, fig. 2. Synonym: Ceratium tasmaniae E.J.F.Wood 1963, nom. inval.

Tripos schroeteri (Schröder 1906) F.Gómez 2013 (三C. schroeteri Schröder).

Sectio Inflata Jørgensen 1911, subsectio Geniculata Jørgensen 1911, subsectio Jørgensen Bigelowia 1911.

Tripos bigelowii (Kofoid 1907a) F.Gómez 2013 (三C. bigelowii Kofoid).

Tripos inflatus (Kofoid 1907a) F.Gómez 2013. Synonyms: C. inflatum (Kofoid) Jørgensen 1911, C. nipponicum Okamura 1912.

Tripos falcatiformis (Jørgensen 1920) F.Gómez, comb. nov. Basionym: Ceratium falcatiforme Jørgensen 1920. Rep. Dan. Oceanogr. Exped. 1908-10 2(J.1): 40, fig. 29.

Tripos falcatus (Kofoid 1907) F.Gómez, comb. nov. Basionym: Ceratium pennatum f. falcatum Kofoid 1907a. Bull. Mus. Comp. Zool. Harvard Coll. 50: 172, pl. 2, fig. 14. Synonym: C. falcatum (Kofoid) Jørgensen 1920.

Tripos geniculatus (Lemmermann 1899) F.Gómez, comb. nov. Basionym: Ceratium fusus var. geniculatum Lemmermann 1899. Abh. Naturw. 
Ver. Bremen 16: 349, pl. 1, fig. 17. Synonyms: C. geniculatum (Lemmermann) Cleve 1900, C. tricarinatum Kofoid 1907a, C. pacificum E.J.F.Wood 1963, nom. illegit.

Tripos pennatus (Kofoid 1907a) F.Gómez, comb. nov. Basionym: Ceratium pennatum f. propium Kofoid 1907b. Bull. Mus. Comp. Zool. Harvard Coll. 50: 172, pl. 2, fig. 12, non figs 13-14. C. longirostrum auct. mult.

Tripos scapiformis (Kofoid 1907a) F.Gómez, comb. nov. Basionym: Ceratium scapiforme Kofoid 1907a. Bull. Mus. Comp. Zool. Harvard Coll. 50: 173, pl. 3, fig. 23.

Sectio of Tripos pacificus, subsectio Beloniformia Jørgensen 1911 in part.

Tripos pacificus (Schröder 1906) F.Gómez, comb. nov. Basionym: Ceratium pacificum Schröder 1906. Vierteljahrsschr. Naturf. Ges. Zürich 51: 368, fig. 42. Synonym: C. belone auct. mult. Non $C$. pacificum E.J.F.Wood 1963, nom. inval.

Subgenus Amphiceratium (Vanhöffen 1896) Ostenfeld 1903, genus Amphiceratium Vanhöffen.

Sectio Fusus Pavillard 1907b, sectio Fusiformia Jørgensen 1911, sectio Amphiceratium (Vanhöffen 1896) Gran 1902.

Tripos fusus (Ehrenberg 1833) F.Gómez 2013. Synonyms: P. fusus Ehrenberg, C. fusus (Ehrenberg) Dujardin 1841, Amphiceratium fusus Vanhöffen 1896, P. seta Ehrenberg 1859a, C. seta (Ehrenberg) 
W.S.Kent 1881, C. berghii Gourret 1883, C. pellucidum Gourret 1883.

Tripos extensus (Gourret 1883) F.Gómez, comb. nov. Basionym: Ceratium fusus var. extensum Gourret 1883. Ann. Mus. Hist. Nat. Marseille 1(8): 52, pl. 4, fig. 56. Synonyms: C. extensum (Gourret) Cleve 1900, $C$. strictum (Okamura et Nishikawa 1904) Kofoid 1906, non C. biceps Claparède et J.Lachmann 1859.

Tripos longirostrum (Gourret 1883) F.Gómez, comb. nov. Basionym: Ceratium longirostrum Gourret 1883. Ann. Mus. Hist. Nat. Marseille 1(8): 55, pl. 4, fig. 65 . Non Ceratium pennatum f. propium Kofoid 1907.

Subgenus Tripos autonym, subgenus Euceratium (Gran 1902) Ostenfeld 1903, Tripoceratium Kofoid 1909, Macroceratium Kofoid 1909, Macroceratium Böhm 1931, Orthoceratium Sournia 1968, non Orthoceratium Meunier 1919.

Sectio Macroceros Ostenfeld 1903, subgenus Macroceratium Kofoid 1909, sectio Macroceros Pavillard 1907b, sectio Protuberantia Karsten 1907, subsectio Deflexa Jørgensen 1011, subsectio Volantia Jørgensen 1911, subsectio Flagellifera Jørgensen 1911, subsectio Tenuia Jørgensen 1911, sectio Trichoceros Böhm 1931.

Tripos carriensis (Gourret 1883) F.Gómez, comb. nov. Basionym: Ceratium carriense Gourret 1883. Ann. Mus. Hist. Nat. Marseille 1(8): 38, pl. 4, fig. 57. Synonyms: C. inflexum (Gourret 1883) Schröder 1906, C. 
flagelliferum Cleve 1900, C. ramakrishnae Subrahmanyan 1968, non C. carriense auct. mult.

Tripos gallicus (Kofoid 1907b) F.Gómez, comb. nov. Basionym: Ceratium gallicum Kofoid 1907b. Univ. Calif. Publ. Zool. 3: 302, pl. 24, figs. 10-12. 1907. Synonyms: C. californiense Kofoid 1907b, C. deflexum (Kofoid 1907b) Jørgensen 1911, C. uncinus Sournia 1972, C. macroceros auct. mult.

Tripos longissimus (Schröder 1900) F.Gómez, comb. nov. Basionym: Ceratium tripos f. longissimum Schröder 1900. Mitt. Zool. Stat. Neapel 14: 16, pl. 1, fig. 17i. Synonym: C. longissimum (Schröder) Kofoid 1907b.

Tripos macroceros (Ehrenberg 1840) F.Gómez, comb. nov. Basionym: Peridinium macroceros Ehrenberg 1840. Ber. K. Akad. Wiss. Berlin 1840: 201. Synonyms: C. macroceros (Ehrenberg) Cleve 1899, C. contrarium (Gourret 1883) Pavillard 1905, C. batavum Paulsen 1907, C. intermedium (Jørgensen 1905) Jørgensen 1911, C. protuberans (G.Karsten 1906) Paulsen 1930, ?C. shameelii Ghazala 2009. Non $C$. macroceros auct. mult.

Tripos massiliensis (Gourret 1883) F.Gómez, comb. nov. Basionym: Ceratium tripos var. massiliense Gourret 1883. Ann. Mus. Hist. Nat. Marseille 1(8): 27, pl. 1, figs. 2, 2a). Synonyms: C. massiliense (Gourret) G.Karsten 1906, C. aequatoriale Schröder 1906, C. 
undulatum Schröder 1906, C. ostenfeldii Kofoid 1907b, ?C. recurvatum Schröder 1906, non C. volans Cleve 1900.

Tripos pavillardii (Jørgensen 1911) F.Gómez, comb. nov. Basionym: Ceratium vultur sensu Pavillard 1905. Trav. Inst. Bot. Univ. Montpellier Stat. Zool. Cette, ser. mixte, Mém. 2: 54, pl. 1, fig. 2; C. pavillardii Jørgensen 1911. Int. Rev. Hydrobiol. u. Hydrogr., Biol. Suppl. 2(1): 74, figs. 157, 158.

Tripos tenuis (Ostenfeld et Johannes Schmidt 1901) F.Gómez, comb. nov. Basionym: Ceratium tenue Ostenfeld et Johannes Schmidt 1901. Vid. Medd. Naturh. For. Kjфbenhavn 1901: 166, fig. 18. Synonym: $C$. inclinatum Kofoid 1907b.

Tripos trichoceros (Ehrenberg 1859a) F.Gómez 2013 (三P. trichoceros Ehrenberg 1859a, C. trichoceros (Ehrenberg) W.S.Kent 1881).

Tripos volans (Cleve 1900) F.Gómez, comb. nov. Basionym: Ceratium volans Cleve 1900. K. Svenska Vet. Akad. Handl., [ser. 4] 34(1): 15, pl. 7, fig. 4. Synonyms: C. patentissimum Ostenfeld et Johannes Schmidt 1901, C. ceylanicum Schröder 1906, C. elegans Schröder 1906, C. hundhausenii Schröder 1906, C. carriense auct. mult.

Sectio Palmata Pavillard 1907b, sectio Platycornia Jørgensen 1911, subsectio Intermedia Jørgensen 1911. 
Tripos claviger (Kofoid 1907) F.Gómez, comb. nov. Basionym: Ceratium claviger Kofoid 1907a. Bull. Mus. Comp. Zool. Harvard Coll. 50: 170, pl. 4 , fig. 27.

Tripos compressus (Gran 1902) F.Gómez, comb. nov. Basionym: Ceratium compressum Gran 1902. Rep. Norw. Fish. Mar. Invest. 2(5): 54, 193, 196, fig. 16. Tripos platycornis is probably a senior synonym.

Tripos intermedius (Jørgensen 1899) F.Gómez, comb. nov. Basionym: Ceratium tripos f. intermedium Jørgensen 1899. Bergens Mus. Aarb. 1899(6): 42: pl. 1, fig. 10. Synonyms: C. intermedium (Jørgensen 1899) Jørgensen 1905, C. denticulatum (Jørgensen 1920) Paulsen 1931, C. molle Kofoid 1907b, C. tenuissimum Kofoid 1907b, C. buceros Zacharias 1906, C. patentissimum Ostenfeld et Johannes Schmidt 1901, C. leptosomum Jørgensen 1911, ?C. inversum G.Karsten, 1907, C. horridum sensu auct.

Tripos platycornis (Daday 1888) F.Gómez, comb. nov. Basionym: Ceratium platycorne Daday 1888. Természetr. Füz. 11: 78, 101, pl. 3, figs. 1, 2. Synonyms: C. lamellicorne Kofoid 1908d, C. dilatatum (G.Karsten 1905) Kofoid 1907a (non C. dilatatum Gourret 1883). Tripos compressus is probably a junior synonym.

Tripos ranipes (Cleve) F.Gómez, comb. nov. Basionym: Ceratium ranipes Cleve 1900. K. Svenska Vet. Akad. Handl., [ser. 4] 34(1): 13, pl. 7, fig. 1. Synonym: Ceratium palmatum (Schröder 1900) Cleve 1901. 
Tripos arcticus (Ehrenberg) F.Gómez, comb. nov. Basionym: Peridinium arcticum Ehrenberg 1853. Ber. K. Akad. Wiss. Berlin 1853: 528. Synonyms: C. arcticum (Ehrenberg) Cleve 1900, C. labradoricum (F.Schütt 1892) Vanhöffen 1897, non C. arcticum sensu Vanhöffen 1897 (=T. longipes).

Tripos longipes (Bailey 1854) F.Gómez, comb. nov. Basionym: Peridinium longipes Bailey 1854. Smithson. Contrib. Knowl. 7(3): 12, fig. 35. Synonyms: C. longipes (Bailey) Cleve 1900, C. arcticum sensu Vanhöffen 1897, C. horridum (Cleve 1897) Gran 1902, non C. horridum sensu Gran 1902, non C. horridum sensu auct. (=Tripos intermedius).

Sectio Vultur (Jørgensen 1911) Böhm 1931, subsectio Vultur Jørgensen 1911, sectio Reflexa Jørgensen 1911, subsectio Reflexa (Jørgensen) P. Reinecke. Tripos reflexus (Cleve 1900) F.Gómez (三C. reflexum Cleve) Tripos robustus (Ostenfeld et Johannes Schmidt 1901) F.Gómez, comb. nov. Basionym: Ceratium robustum Ostenfeld et Johannes Schmidt, 1901. Vid. Medd. Naturh. For. Kjøbenhavn 1901: 166, fig. 17. Synonym: $C$. japonicum Schröder 1906.

Tripos vultur (Cleve 1900) F.Gómez, comb. nov. Basionym: Ceratium vultur Cleve 1900. K. Svenska Vet.-Akad. Handl., [ser. 4] 34(1): 15, pl. 7, fig. 5. Synonyms: C. sumatranum (G.Karsten 1907) Jørgensen 1911, C. recurvum (Jørgensen 1911) P.Reinecke 1973.

Sectio Reticulata (Jørgensen 1911) Böhm 1931, subsectio Reticulata Jørgensen. 
Tripos hexacanthus (Gourret 1883) F.Gómez 2013. Synonyms: C. hexacanthum Gourret 1883, C. reticulatum (Pouchet 1883) Cleve 1903, C. aestuarium Schröder 1911, ?C. obesum Pavillard 1930.

Sectio Tripos autonym, sectio Tripos Ostenfeld 1903, Pavillard 1907b, sectio Euceratium Gran 1902, sectio Rotunda G.Karsten 1907, subsectio Eutripos Jørgensen 1911, sectio Dens Jørgensen 1911.

Tripos brevis (Ostenfeld et Johannes Schmidt 1901) F.Gómez, comb. nov. Basionym: Ceratium tripos var. breve Ostenfeld et Johannes Schmidt 1901. Vid. Medd. Naturh. For. Kjфbenhavn 1901: 164, fig. 13. Synonym: C. breve (Ostenfeld et Johannes Schmidt) Schröder 1906.

Tripos dens (Ostenfeld et Johannes Schmidt 1901) F.Gómez 2013. Synonyms: C. dens Ostenfeld et Johannes Schmidt 1901, C. balechii Meave del Castillo, Okolodkov et Zamudio 2003, C. divaricatum sensu Kofoid 1908c, non C. divaricatum (Lemmermann 1899) Kofoid $1908 c$.

Tripos gracilis (Pavillard 1905) F.Gómez 2013. Synonyms: C. gracile Pavillard 1905, C. declinatum G.Karsten 1907, C. varians Mangin 1922, C. declinatum auct. mult.

Tripos muelleri Bory 1825. Synonyms: Cercaria tripos O.F.Müller 1777, Peridinium tripos (O.F.Müller) Ehrenberg 1833, C. tripos (O.F. Müller) Nitzsch 1817, C. neglectum Ostenfeld 1903, C. subsalsum (Ostenfeld 1903) Apstein 1911, C. dalmaticum Schröder 1911, C. divaricatum (Lemmermann 1899) Kofoid 1908c, non C. divaricatum 
sensu Kofoid 1908c, C. schmidtii Jørgensen 1911, C. humile Jørgensen 1911, C. porrectum (G.Karsten 1907) Jørgensen 1911, C. tripodioides (Jørgensen 1920) Steemann Nielsen 1934, C. schroderi D.S.Nie 1936, C. truncatum (Lohmann 1908) Apstein 1911, ?C. egyptiacum Halim 1963.

Tripos pulchellus (Schröder 1906) F.Gómez, comb. nov. Basionym: Ceratium pulchellum Schröder 1906. Vierteljahrsschr. Naturf. Ges. Zürich 51: 358, fig. 27. Synonym: C. semipulchellum Steemann Nielsen 1934.

Subsectio Arcuata Karsten 1907, subsectio Arcuata Jørgensen 1911.

Tripos arcuatus (Gourret 1883) F.Gómez, comb. nov. Basionym: Ceratium tripos var. arcuatum Gourret 1883. Ann. Mus. Hist. Nat. Marseille 1(8): 25, pl. 2, fig. 42. Synonyms: C. arcuatum (Gourret) Vanhöffen 1897, C. euarcuatum Jørgensen 1920, C. filicorne Steemann Nielsen 1934, C. angusticornum (Peters 1932) Steemann Nielsen 1939, C. okamurae B. Schröder 1906.

Tripos axialis (Kofoid 1907a) F.Gómez 2013 (三C. axiale Kofoid 1907a).

Tripos coarctatus (Pavillard 1905) F.Gómez, comb. nov. Basionym: Ceratium coarctatum Pavillard 1905. Trav. Inst. Bot. Univ. Montpellier Stat. Zool. Cette, ser. mixte, Mém. 2: 52, pl. 1, fig. 6.

Tripos karstenii (Pavillard 1907a) F.Gómez, comb. nov. Basionym: Ceratium karstenii Pavillard 1907a. Bull. Soc. Bot. France 54: 152. Synonym: C. schrankii Kofoid 1907b. 
Tripos longinum (G.Karsten 1906) F.Gómez, comb. nov. Basionym: Ceratium tripos var. longinum G. Karsten 1906. Wiss. Ergeb. Deutsch. Tiefsee-Exped. 1898-1899, 2(2): 143, pl. 21, fig. 18.

Tripos subcontortus (Schröder 1906) F.Gómez, comb. nov. Basionym: Ceratium subcontortum Schröder 1906. Vierteljahrsschr. Naturf. Ges. Zürich 51: 358, fig. 28. Synonym: C. saltans Schröder 1906, C. contortum auct. mult.

Tripos symmetricus (Pavillard 1905) F.Gómez, comb. nov. Basionym: Ceratium symmetricum Pavillard 1905. Trav. Inst. Bot. Univ. Montpellier Stat. Zool. Cette, ser. mixte, Mém. 2: 52, pl. 1, fig. 4. Synonym: C. orthoceras (Jørgensen 1911) Pavillard 1931.

Sectio Limulus Jørgensen 1911, subsectio Lunulae Jørgensen 1911.

Tripos arietinus (Cleve) F.Gómez, comb. nov. Basionym: Ceratium arietinum Cleve 1900. K. Svenska Vet.-Akad. Handl., [ser. 4] 34(1): 13, pl. 7, fig. 3. Synonyms: C. arietinum Cleve 1900, C. bucephalum (Cleve 1897) Cleve 1900, C. heterocamptum (Jørgensen 1899) Ostenfeld et Johannes Schmidt 1901.

Tripos azoricus (Cleve 1900) F.Gómez 2013 (三C. azoricum Cleve 1900).

Tripos carnegiei (H.W.Graham et Bronikovsky 1944) F.Gómez 2013 (三C. carnegiei H.W.Graham et Bronikovsky 1944).

Tripos limulus (C.H.G.Pouchet 1883) F.Gómez, comb. nov. Basionym: Ceratium tripos var. limulus C.H.G.Pouchet 1883. J. Anat. Physiol. 
19: 424, pl. 18+19, fig. 4. Synonym: C. limulus (C.H.G.Pouchet) Gourret 1883.

Tripos lunula (A. Schimper in Chun 1900 ex G.Karsten 1906) F.Gómez 2013 (三C. lunula A. Schimper in Chun 1900 ex G.Karsten 1906).

Tripos paradoxides (Cleve 1900) F.Gómez 2013 (三C. paradoxides Cleve 1900).

Tripos petersii (Steemann Nielsen 1934) F.Gómez 2013 (三C. petersii Steemann Nielsen). Probably a synonym of T. azoricus.

Subsectio Gibbera Jørgensen 1911.

Tripos gibberum (Gourret 1883) F.Gómez, comb. nov. Basionym: Ceratium gibberum Gourret 1883. Ann. Mus. Hist. Nat. Marseille 1(8): 34, pl. 2, fig. 35. Synonyms: C. curvicornis (Daday 1888) Cleve 1900, C. contortum (Gourret 1883) Cleve 1900, C. concilians Jørgensen 1920, non C. contortum auct. mult.

\section{Conclusions}

About 165 species and 800 infraspecific taxa of Tripos have been proposed. The current molecular data with sequences of 30, 9 and 3 species for the SSU-, LSU- and ITS rRNA gene markers, respectively, are insufficient to solve the speciation of the genus. In the SSU- and LSU rRNA gene phylogenies, the sequences of the subgenera Amphiceratium, Archaeceratium and Tripos eugrammus (=T. furca auct. mult.) were the basal clades, while the sequences of the typical anchor-shaped species clustered in the distal groups. The 


\section{ScienceOpen Preprints}

reinstatement of the genera Amphiceratium, Biceratium and Poroceratium have several problems. The diagnostic characters to circumscribe Poroceratium are unclear, especially after encompassing most of the species of Amphiceratium (section Inflata, and most of the species of the section Fusiformia). There are no molecular data of key species such as $T$. belone and T. pacificus that could be a link between Archaeceratium and Amphiceratium, and there is no any LSU rRNA gene sequence of species of Poroceratium. For the reinstatement of Biceratium, LSU rRNA gene sequences of only two species are available and they did not cluster together. The SSU rRNA gene sequences of T. eugrammus and the members of the sections Furciformia, Pentagona and Candelabra did not cluster as a monophyletic group. Consequently, a tentative split of Tripos needs more molecular data and morphological studies to define the diagnostic characters of the tentative segregated genera.

The review of the original species descriptions reveals that the names T. eugrammus and T. furca should be used for the species currently identified as T. furca and T. lineatus, respectively. The names $T$. pacificus and T. carriensis have been misapplied for T. belone. and $T$. volans, respectively. The species names $T$. arcuatus, $T$. gracilis, $T$. inclinatus, $T$. scapiformis and T. subcontortus are revived to replace T. euarcuatus, T. declinatus, $T$. horridus, T. longirostrum and T. contortus, respectively. Rare species were described from autotomized individuals such as $C$. californiense or $C$. ehrenbergii. Other species were described from aberrant individuals such as $C$. deflexus, $C$. obesus, $C$. reflexus, $C$. shameelii or $C$. uncinnus. The individuals infected by an endoparasites exhibit an expanded midbody, being described as distinct species such as C. ramanskiniae or C. fusus var. schuettii. Fiftyseven correct species are considered from the 165 names of marine species of Ceratium proposed in the literature. Our knowledgement of the speciation and evolution of the genus Tripos is largely incomplete due to lack of studies in the life cycle and molecular data. 


\section{Acknowledgements}

This research was funded by the Spanish Ministry of Science and Technology, grant number MEC2007\#0213; French CNRS ANR Biodiversity program “Aquaparadox”, grant number ANR-07-BDIV-004; the Spanish Ministry of Science and Technology, grant number JCI2010-08492; and the Brazilian Conselho Nacional de Desenvolvimento Científico e Tecnológico, grant number BJT 370646/2013-14.

\section{References}

Apstein, C., 1911. Biologische Studie über Ceratium tripos var. subsalsa. Wissenschaftliche Meeresuntersuchungen, Kiel 12: 137-162.

Bailey, J. W., 1854. Notes on new species and localities of microscopical organisms. Smithsonian Contributions to Knowledge, 7 (3): 1-15.

Balech, E., 1988. Los dinoflagelados del Atlántico Sudoccidental. Publicaciones Especiales del Instituto Español de Oceanografía, 1: 1-310.

Bergh, R. S., 1881. Der organismus der Cilioflagellaten. Eine phylogenetische studie. Morphologisches Jahrbuch, 7 (2): 177-288.

Böhm, A., 1931. Distribution and variability of Ceratium in the northern and western Pacific. Bernice P. Bishop Museum, Honolulu, 87: 1-47.

Claparède, É. and Lachmann, J., 1859. Études sur les infusoires et les rhizopodes. Memoires de l'Institut National Genevois, 6: 261-482. 
Cleve, P. T., 1897. Report on the phyto-plankton collected on the expedition of H.M.S. 'Research', 1896. Annual Report of Fisheries Board of Scotland, 15 (3): 297-304.

Cleve, P. T., 1900. Notes on some Atlantic plankton-organisms. Kungliga Svenska Vetenskapsakademiens Handlingar, 34: 1-22.

Ehrenberg, C. G., 1834. Dritter Beitrag zur Erkenntniss grosser Organisation in der Richtung des kleinsten Raumes. Abhandlungen der Königlichen Akademie der Wissenschaften zu Berlin, 1833: 145-336.

Ehrenberg, C. G., 1854a. Die systematische charakteristik der neuen mikroskopischen organismen des tiefen atlantischen Oceans für den monatsbericht zum druck zy übergeben. Bericht über die Zur Bekanntmachung Geeigneten Verhandlungen Der Königlich Preussische Akademie der Wissenschaften zu Berlin, 1854: 236-250.

Ehrenberg, C. G., 1854b. Mikrogeologie. Einundvierzig Tafeln mit über viertausend grossentheils colorirten Figuren, Gezeichnet vom Verfasser. Voss, Leipzig.

Ehrenberg, C. G. 1873. Die das Funkeln und Aufblitzen des Mittelmeeres bewirkenden kleinen Lebensformen. Festschrift zur Feier des hundertjährigen Bestehens der Gesellschaft Naturforschender Freunde zu Berlin, 1-4.

Gaarder, K. R., 1954. Dinoflagellatae from the "Michael Sars" North Atlantic Deep-Sea Expedition 1910. Reports on the scientific results of the "Michael Sars" North Atlantic Deep-Sea Expedition 1910, 2 (3): 1-62.

Ghazala, B., 2009. New species of Ceratium (Dinophycota) from coastal water of Balochistan. International Journal of Phycology and Phytochemistry, 5 (1): 55-56. 
Gómez, F., 2013. Reinstatement of the dinoflagellate genus Tripos to replace Neoceratium, marine species of Ceratium (Dinophyceae, Alveolata). CICIMAR Oceanides, 28 (1): 122.

Gómez, F., Claustre, H. and Souissi, S., 2008. Rarely reported dinoflagellates of the genera Ceratium, Gloeodinium, Histioneis, Oxytoxum and Prorocentrum (Dinophyceae) from the open southeast Pacific Ocean. Revista de Biología Marina y Oceanografía, 43 (1): $25-40$.

Gómez, F., López-García, P. and Moreira, D. 2011. Molecular phylogeny of dinophysoid dinoflagellates: the systematic position of Oxyphysis oxytoxoides and the Dinophysis hastata group (Dinophysales, Dinophyceae). Journal of Phycology, 47 (2): 393-406.

Gómez, F., Moreira, D. and López-García, P., 2010. Neoceratium gen. nov., a new genus for all marine species currently assigned to Ceratium (Dinophyceae). Protist, 161 (1): 3554.

Gourret, P., 1883. Sur les Peridiniens du Golfe de Marseille. Annales du Musée d'histoire naturelle de Marseille, 1: 1-114.

Graham, H. W. and Bronikovsky, N., 1944. The genus Ceratium in the Pacific and North Atlantic oceans. Scientific results of cruise VII of the Carnegie during 1928-1929 under command of Captain J.P. Ault. Carnegie Institute of Washington. Publications, 565: 1209.

Gran, H. H., 1902. Das Plankton des Norwegischen Nordmeeres von biologischen und hydrographischen Gesichtspunkten behandelt. Report of the Norwegian Fishery and Marine Investigations, 2 (5): 1-222. 
Halim, Y., 1963. Microplancton des Eaux Égyptiennes. Le genre Ceratium Schrank (Dinoflagellés). Rapports et Procès-Verbaux des Réunions du Conseil Permanent International pour l'Exploration de la Mer, 17: 495-502.

Jørgensen, E., 1911. Die Ceratien. Eine kurze Monographie der Gattung Ceratium Schrank. Internationale Revue der Gesamten Hydrobiologie und Hydrographie 4, Supplement, 1: $1-124$.

Jørgensen, E., 1920. Mediterranean Ceratia. Report on the Danish oceanographical expeditions 1908-10 to the Mediterranean and adjacent seas 2. Biology, J. 1, 1-110.

Karsten, G., 1905. Das Phytoplankton des Antarktischen Meeres nach dem Material der deutschen Tiefsee-Expedition 1898-1899. Wissenschaftliche Ergebnisse der Deutschen Tiefsee-Expedition auf dem Dampfer "Valdivia" 1898-1899, 2 (2): 1-136.

Karsten, G., 1906. Das Phytoplankton des Atlantischen Oceans nach dem Material der Deutschen Tiefsee-Expedition 1898-1899. Wissenschaftliche Ergebnisse der Deutschen Tiefsee-Expedition auf dem Dampfer "Valdivia" 1898-1899, 2 (2): 137-219.

Karsten, G., 1907. Das Indische Phytoplankton nach dem Material der deutschen TiefseeExpedition 1898-1899. Wissenschaftliche Ergebnisse der Deutschen Tiefsee-Expedition auf dem Dampfer "Valdivia" 1898-1899, 2 (2): 221-548.

Kofoid, C. A., 1907a. Reports on tbe Scientific Results of the Expedition to the Eastern Tropical Pacific, in charge of Alexander Agassiz, by the U.S. Fish Commission Steamer “Albatross”, from October, 1904, to March, 1905, Lieut. Commander L. M. Garrett, U. S. N., commanding. IX. New species of Dinoflagellates. Bulletin of the Museum of Comparative Zoology, Harvard College, 50: 161-207. 
Kofoid, C. A., 1907b. Dinoflagellata of the San Diego region. III. Description of new species. University of California Publications in Zoology, 3: 299-340.

Kofoid, C. A., 1908a. On Ceratium eugrammum and its related species. Zoologischer Anzeiger, 32: 25-28.

Kofoid, C. A., 1908b. The plates of Ceratium with a note on the unity of the genus. Zoologischer Anzeiger, 32: 177-183.

Kofoid, C. A., 1908c. Exuviation, autotomy and regeneration in Ceratium. University of California Publications in Zoology, 4: 345-386.

Kofoid, C. A., 1908d. Notes on some obscure Ceratium species. University of California Publications in Zoology, 4: 387-393.

Kofoid, C. A., 1909. Mutations in Ceratium. Bulletin of the Museum of Comparative Zoology, Harvard College, 52: 215-222.

Kumar, S., Stecher, G. and Tamura, K., 2016. MEGA7: Molecular Evolutionary Genetics Analysis Version 7.0 for Bigger Datasets. Molecular Biology and Evolution, 33 (7): $1870-1874$.

Larkin, M. A., Blackshields, G., Brown, N. P., Chenna, R., McGettigan, P. A. et al., 2007. Clustal W and Clustal X version 2.0. Bioinformatics, 23 (21): 2947-2948.

Lebour, M. V., 1925. The dinoflagellates of northern seas. Marine Biological Association of the United Kingdom, Plymouth. 250p.

Lemmermann, E., 1899. Ergebnisse einer Reise nach dem Pacific. (H. Schauinsland 1896/97). Abhandlungen Naturwissenschaftlicher Verein zu Bremen, 16 (2): 313-398. 


\section{ScienceOpen Preprints}

Lohmann, H., 1908. Untersuchungen zur Feststellung des vollständigen Gehaltes des Meeres an Plankton. Wissenschaftliche Meeresuntersuchungen Kiel, 10: 129-370.

Meave del Castillo, M. E., Zamudio Resendiz, M. E., Okolodkov, Y. B. and Salgado Ugarte, I. H., 2003. Ceratium balechii sp. nov. (Dinophyceae: Gonyaulacales) from the Mexican Pacific. Hidrobiológica, 13 (1): 75-91.

Ostenfeld, C. H., 1903. Phytoplankton from the sea around the Færöes. Botany of the Faröes, 2: $558-612$.

Ostenfeld, C. H. and Schmidt, J., 1901. Plankton fra det Rode Hav og Abenbugten (Plankton from the Red Sea and the Gulf of Aden). Videnskabelige Meddelelser Dansk Naturhistorisk Forening, 25: 161-182.

Paulsen, O., 1908. Peridiniales. In: Brandt, K. and Apstein, C. (Eds.). Nordisches Plankton. Botanischer Teil 8. Lipsius \& Tischer, Kiel and Leipzig. p. 1-124.

Pavillard, J., 1905. Recherches sur la flore pélagique (Phytoplankton) de l'Étang de Thau. Travail de l'Institut de Botanique de l'Université de Montpellier et de la Station Zoologique de Cette. Serie mixte. Cette, serie mixte, Mémoires, 2: 5-116.

Pavillard, J., 1907a. Sur les Ceratium du Golfe du Lion. Bulletin de la Société Botanique de France, 54: 148-154.

Pavillard, J., 1907b. Sur les Ceratium du Golfe du Lion (2e Note). Bulletin de la Société Botanique de France, 54: 225-231.

Pavillard, J., 1931. Phytoplankton (Diatomées, Péridiniens): provenant des campagnes scientifiques du Prince Albert $\mathrm{I}^{\mathrm{er}}$ de Monaco. Imprimerie de Monaco, Montecarlo. 
Peters, N., 1932. Die Bevolkerung des Südatlantischen Ozeans mit Ceratien. Wissenschaftliche Ergebnisse der Deutschen atlantischen Expedition "Meteor" 1925 1927, 12: 1-69.

Rampi, L., 1942. Ricerche sul fitoplancton del mare Ligure. 1. Ceratium. 1942 delle acque di Sanremo, parte 2. Nuovo Giornale Botanico Italiano n.s., 49 (2): 221-236.

Schiller, J., 1937. Dinoflagellatae (Peridineae) in Monographischer Behandlung. Rabenhorst's Kryptogamen. Flora. Bd. 10, Akad. Verlag, Leipzig 1 (3): 433-617.

Schröder, B., 1900. Das Phytoplankton des Golfes von Neapel. Mittheilungen aus der Zoologischen Station zu Neapel, 14: 1-38.

Schröder, B., 1906. Beiträge zur Kenntnis des Phytoplanktons warmer Meere. Vierteljahrsschrift der Naturforschenden Gesellschaft in Zürich, 51: 319-377.

Schröder, B., 1909. Phytoplankton von Westindien. Berichte der Deutschen Botanischen Gesellschaft, 27: 210-214.

Schütt, F., 1892. Das Pflanzenleben der Hochsee. Ergebnisse der Plankton-Expedition der Humboldt Stift, 1A: 243-324.

Schütt, F., 1895. Die Peridineen der Plankton-Expedition. Ergebnisse der PlanktonExpedition der Humboldt Stift, 4: 1-170.

Sournia, A., 1968. Le genre Ceratium (péridinien planctonique) dans le canal de Mozambique. Contribution à une révision mondiale. Vie et Milieu, 18 (2-3A): 375-499.

Steidinger, K. A. and Tangen, K., 1997. Dinoflagellates. In: Tomas, C. R. (Eds). Identifying marine phytoplankton. Academic Press, San Diego. p. 387-589 
ScienceOpen Preprints

Stüwe, W., 1909. Phytoplankton aus dem Nord-Atlantik im Jahre 1898 u. 1899. Botanische Jahrbücher, 43: 225-302.

Steemann Nielsen, E., 1934. Untersuchungen über die Verbreitung, Biologie und Variation der Ceratien im südlichen Stillen Ozean. Dana Reports, 1 (4): 1-68.

Subrahmanyan, R., 1968. The Dinophyceae of the Indian Seas. Part 1. Genus Ceratium Schrank. Marine Biological Association of India, Memories, 2 (2): 1-129.

Taylor, F. J. R., 1976. Dinoflagellates from the International Indian Ocean Expedition. A report on material collected by the R.V. 'Anton Bruun' 1963-1964. Bibliotheca Botanica, 132: 1-234.

Vanhöffen, E., 1896. Das Genus Ceratium. Zoologischer Anzeiger 19: 133-134.

Vanhöffen, E., 1897. Die Fauna und Flora Grönlands. Grönland-Expedition der Gesellschaft für Erdkunde zu Berlin 1891-1893 unter Leitung von Erich von Drygalski, Zweiter Band (I). W.H. Kühl, Berlin.

Wood, E. J. F., 1963. Dinoflagellates in the Australian region. II. Recent collections. CSIRO Australia Division of Fisheries and Oceanography, Technical Paper, 14: 4-51.

Zacharias, O., 1906. Über Periodizität, Variation und Verbreitung verschiedener Planktonwesen in südlichen Meeren. Archiv fur Hydrobiologie, 1: 498-575. 